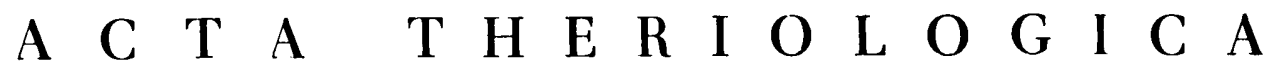

VOL. IX, 19: 305-352.

BIAEOWIEŻA

30.XII.1964

\author{
JAN R A C Z Y N S K I
}

\title{
Studies on the European Hare. V. Reproduction
}

\author{
Badania nad zającem szarakiem. V. Rozród
}

[With 10 Figs. \& 5 Tables]

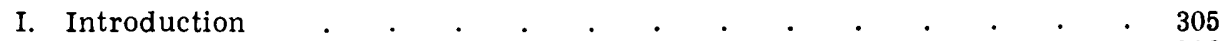

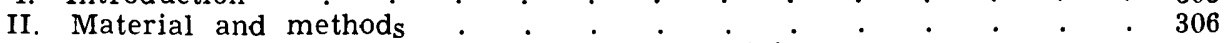

III. Description of the yearly cycle of sexual activity
A. Males
1. Weight and dimensions of the testes . . . . . . 307
2. Participation of males in reproduction . . . . . . . 309
B. Females
1. Size and condition of reproductive system . . . . . . 316
2. Participation of females in reproduction . . . . . . $\quad 321$
C. Comparison of the sexual activity cycles of males and females. . 323

IV. Efficiency of reproduction

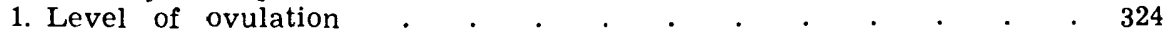

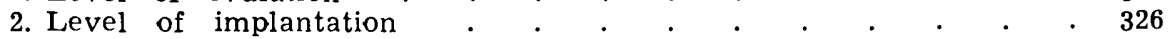

3. Embryonic mortality . . . . . . . . . . . . 327

a. Mortality before implantation . . . . . . . 327

b. Resorption of embryos . . . . . . . . . . . . . $\quad . \quad . \quad 328$

4. Size of litter . . . . . . . . . . . . . . . . . . . $\quad . \quad 329$

5. Number of litters in one year $. \quad . \quad . \quad+\quad . \quad . \quad . \quad . \quad . \quad 332$

6. Numerical increase of young animals . $. \quad . \quad . \quad . \quad . \quad . \quad . \quad 333$

V. Sex ratio. . . . . . . . . . . . . . . 334

VI. Some other problems of reproduction physiology . . . . . . . 337

VII. Discussion

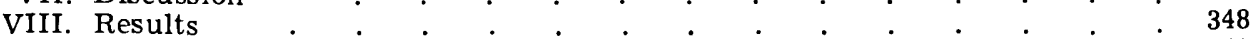

References . . . . . . . . . . . . . . . . . 349

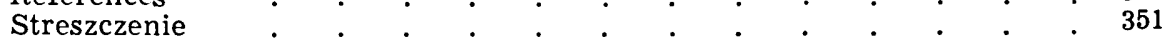

\section{INTRODUCTION}

The European hare is now treated as one of the basic species of game animals. Despite the commonness of this animal and the ease with which material can be obtained for research, the hare has not formed the subject of exhaustive studies, not only from the biological aspect, but even from the standpoint of strictly practical hunting purposes. Although a relatively large number of publications 
refer to problems of the hare's reproduction, here also this question has been far from fully dealt with. An illustration of this is provided by the fact that even the duration of pregnancy in the hare has been determined only comparatively recently, after successfull attempts at breeding the animals in captivity (H e d i$\mathrm{g}$ e $r$, 1948). Progress in research on the anatomy and physiology of the genital system of the hare is due to the observations made during recent years ( $\mathrm{S}$ t i eve, 1952; B loch et al., 1954, 1963; B lo ch \& Straus s, 1958).

In literature so far published a relatively large number of studies refer to the reproduction biology of the European hare. Studies have been made of these questions on material from Eastern Europe by Kolos ov (1941), K olo s o v \& B a ke v (1947), from Central Europe by $\mathrm{S} t \mathrm{i}$ e ve (1952), R i e c k (1956), Valentincic (1956), S c arlatescu et al. (1963), for the European hare introduced into Canada, by Reynolds \& Stinson (1959). This problem was also studied in related species: Lepus timidus L i n n e u s, 1758 (N a umov, 1960), Lepus tibetanus W a t e r house, 1841 (P i e revalov, 1956) and for several American species of the genus Lepus (Sowls, 1957; Lechle it ner, 1959) and Sylvilagus (S chwar tz, 1942).

The studies referred to above do not, however, deal exhaustively with the problem on account of the generally scanty study material, not infrequently an incomplete yearly cycle and also the fact that it was taken from different parts of the wide living range of the European hare. If in addition we take into consideration the considerable differences in the course taken by reproduction in different years, then it becomes evident that further research is essential if a more exact knowledge is to be obtained of the reproduction process.

The aim of the present study is to trace reproduction in the hare over the full yearly cycle and the life cycle and to attempt to relate the phenomena studied to population relations. This problem, of importance to planned game management, has not so far been studied in detail in Poland.

\section{MATERIAL AND METHODS}

The hares used for the purposes of the present rtudy were taken from the Poznan province (West Poland) and represent random series consisting each of 50 individuals from 15 consecutive months, from December 1958 to February 1960 inclusive (Tab. 1), (page 310).

The material, consisting of the genital organs, was taken from animals dissected about 2 days after they had been shot and sent from the Poznan area to the laboratory in Warsaw. In the case of males the testes were prepared together with the epididymis and in females the uterus together with part of the vagina and ovaries. The prepared organs were preserved in $80 \%$ methyl alcohol and were studied in this form. The whole of the material consisted of the genital organ $_{S}$ of 391 males and 349 females (Tab. 1).

$\mathrm{M}$ a les. The testes, together with the epididymis, after being cleaned of fatty tissue, were rinsed in running water for about 24 hours, then, after being dried on cellulose tissue, were weighed on an analytical scale with accuracy up to $0.01 \mathrm{~g}$. The weight of the preserved material, although different from that of fresh organs, made it possible to grasp variations in weight. Linear measurements of the testes were made with a technical sliding scale, measuring in $\mathrm{mm}$ the length 
(excluding the extension of the epididymis), breath and thickness of the testes. The numerical value describing the relative value of the organ was calculated by multiplying these figures. Volume was calculated in order to obtain a fuller description of the material, in view of the considerable number of gonads damaged during preparation (loss of part or whole of the tail of the epididymis) making it impossible to use the weight finding in such cases. Weighing and measurements were made for each testis separately, the calculated mean value being used in further work.

Spermatogenesis was defined chiefly by means of smears from the epididymis. This method was used for the hare by Kolosov, (1941) and also by other authors (Kolos o v \& B a k e v, 1947; P i r e valov, 1956) on account of its convenience. When this method was used it was found that the time testes well-fixed in alcohol were kept did not significantly affect a correct diagnosis. In certain cases supplementary histological examinations were made, staining the testes with Meyer's haematoxylin and erythrosine.

Females. The ovaries were weighed and measured in an analogical way to that used for testes. Morphological examination of the ovaries was made on the basis of a macroscopic analysis of the structure of their cross-sections. This consisted in the preparation, using a razor, of thin specimens from the whole gonad and observation of the number, arrangement and dimensions of corpora lutea. In order to describe the corpora their maximum diameter in $\mathrm{mm}$ was measured. Measurement was made on the horns of the uterus of the length of the horn and its mean breadth. The interior of the uterus was macroscopically examined after it had been cut open to ascertain whether there were any traces of pregnancy or implantation had taken place. In the case of pregnant females the number of foeti in the horns of the uterus, and the degree to which their development had progressed, were determined by dissection. For this purpose measurements of the foetal thickenings of the uterus and the embryos corresponding to them were made, the size of which, depending on the stage of pregnancy, were expressed by measurement of the total length or the crown-rump length after Godlewski (1956). Particular attention was paid to the arrangement of foeti in both horns of the uterus and the number of corpora lutea in the gonads corresponding to them and to the stages of resorption of embryos.

In addition, on the basis of the structure of the gonads, sex was determined in embryos exceeding $30 \mathrm{~mm}$ in length. In the case of embryos below $60 \mathrm{~mm}$ in length sex was established by the histological method exclusively. The sections were stained with haematoxylin and erythrosin.

\section{DESCRIPTION OF THE YEARLY CYCLE OF SEXUAI ACTIVITY}

\section{A. MALES}

\section{Weight and Dimensions of the Testes}

The weight of the testes together with its appendages, being subject to considerable variations over the yearly cycle, was treated as an index of the functional condition of the sex organs of the males. The course taken by variations in the weight of the testes during the study 


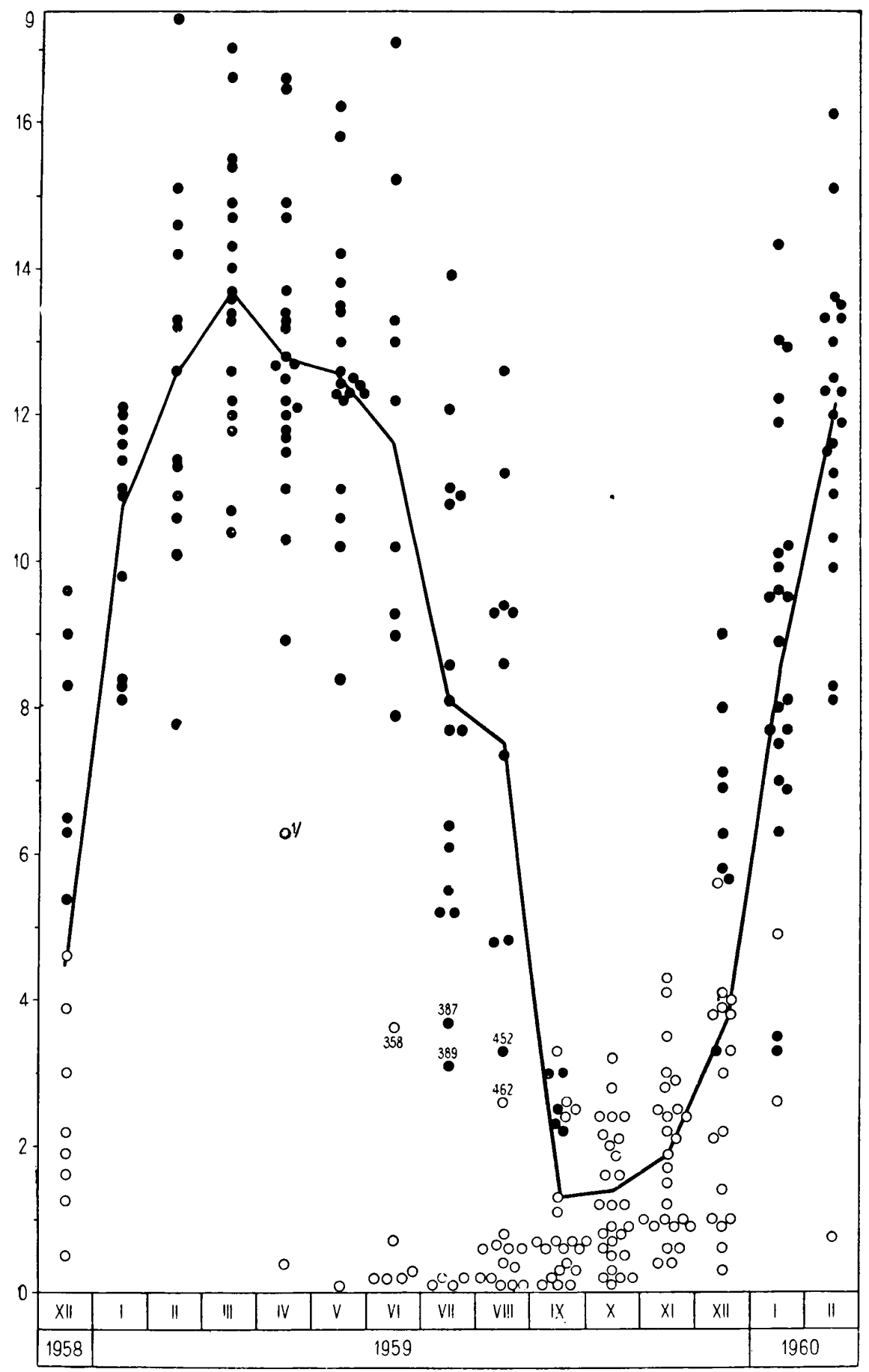

Fig. 1. Variations in the weight of the testes during the yearly cycle. - spermatozoa present in epididymis; $\bigcirc$ - spermatozoa absent in epididymis; - mean weight of the testes (exclusively juv. in months April - August). 1) specimen No. 203 with symptoms of senile regression. 
period is illustrated by figure 1. The mean weight of testes in adult males in December is $4.5 \mathrm{~g}$, after which it rises sharply in the following months to reach a maximum in March (13.7 g). The curve of weight is maintained on a high level from April to June, after which it falls suddenly to $8.14 \mathrm{~g}$ in July and is maintained on a level of $7.46 \mathrm{~g}$ in August. It is not until September and October that sharp regression of the testes reduces weight to the minimum values.

The young specimens appearing in the material in April have testes weighing as a rule less than 1 gramme $(\bar{x}=0.09$ in May and $0.64 \mathrm{~g}$ in June). The testes of occasional young specimens attain the weight of $3.6 \mathrm{~g}$ (specimen from June).

In September the weight of the testes of both young and old males is evened up to a great extent on account of the regression of the gonads in adult individuals, and comes within a narrow range of variations not exceeding $3.5 \mathrm{~g}$. This state is further maintained in October and November. During this period it is impossible to separate the young animals from the old on the basis of the weight of the gonads. It is also impossible to use the external appearance of the testis as a basis for division between young and old. The intense reduction in the head of the epididymis is characteristic the ducts of which do not reveal the lumen visible macroscopically during the period of activity.

The increase in weight of the gonads became apparent in December in 1959. The range of individuals variations in weight was from $0.3-$ $9.0 \mathrm{~g}$ during this period, it being possible to divide the material here into sexually active and inactive specimens.

During the summer and winter periods considerable individual variation in the weight of the testes occurs in adult males (e.g. the range inFebruary was from $7.8-17.4 \mathrm{~g}$, in June from $7.9-17.1 \mathrm{~g})$. Variations in the weight of gonads in males generally (young and old) is markedly narrowed during the period of intensive regression from September to November (range from $0.1-4.3 \mathrm{~g}$ ).

The curve of variations in the weight of the testes coincides with the course taken by the curve of volume of the gonads. This indicates that the index of volume used is sufficiently accurate to obtain a correct description of the size of the testes.

\section{Participation of Males in Reproduction}

The presence in a sperm smear from the epididymis of at least several concentrations of spermatozoa of normal structure, or their absence in the smear, were taken as criteria for dividing males into sexually active 
or inactive specimens. Individuals in which symptoms of regression of the gonads were observed, and in the sperm smear of which only a small amount of deformed spermatozoa were found (residual tails, decomposing spermatozoa) were also treated as sexually inactive. 'In certain individuals a small number of spermatozoa are encountered in smears during the period preceding the end of sexual activity. Judging by the weight of the testes in this period (Fig. 1) and by histological observations, it is a question here of the phenomenon described in the rabbit by Asdell \& $\mathrm{Hammond}$ (cited after Kolosov'\& Ba$\mathrm{keev}, 1947$ ) of the spermatozoa being retained in the ducts of the

Table 1.

Comparison of material.

\section{Table 2.}

Sexual activity of males.

* - one specimens with manifestations of senile regression; ** - including 4 specimens with spermatozoa dissappearing from the excretory ducts.

\begin{tabular}{|c|c|c|c|c|c|c|}
\hline \multicolumn{3}{|c|}{ Date } & \multirow{2}{*}{$\mathrm{N}$} & \multicolumn{3}{|c|}{ Material used } \\
\hline Year & Wonth & Days & & $\overline{\delta \delta}$ & $q \circ$ & Total \\
\hline 1958 & $X I I$ & $6-11$ & 47 & 15 & 26 & 41 \\
\hline \multirow{12}{*}{1959} & $I$ & $16-24$ & 55 & 27 & 27 & 54 \\
\hline & II & $13-19$ & 48 & 20 & 27 & 47 \\
\hline & I I I & $14-21$ & 50 & 23 & 26 & 49 \\
\hline & IV & $18-54$ & 55 & 33 & 20 & 53 \\
\hline & V & $16-22$ & 57 & 33 & 23 & 56 \\
\hline & VI & $13-19$ & 51 & 35 & 11 & 46 \\
\hline & VII & $11-16$ & 47 & 22 & 20 & 42 \\
\hline & $V I J I$ & $15-21$ & 54 & 23 & 26 & 49 \\
\hline & $I X$ & $12-17$ & $5 i 2$ & 25 & 22 & 47 \\
\hline & $x$ & $16-23$ & 55 & 27 & 26 & 53 \\
\hline & $X I$ & $14-19$ & 51 & 26 & 24 & 50 \\
\hline & $X I I$ & $12-17$ & 56 & 26 & $<9$ & 55 \\
\hline \multirow{2}{*}{1960} & $I$ & $16-21$ & 41 & 24 & 17 & 41 \\
\hline & II & $13-19$ & 46 & 21 & 25 & 46 \\
\hline \multicolumn{3}{|c|}{ Total } & 765 & 380 & 349 & 729 \\
\hline
\end{tabular}

\begin{tabular}{|c|c|c|c|c|c|c|}
\hline \multirow{2}{*}{ rear } & \multirow{2}{*}{ lionth } & \multirow{2}{*}{$\mathrm{N}$} & \multicolumn{2}{|c|}{ Act 1 ve } & \multicolumn{2}{|c|}{ Inactive } \\
\hline & & & $n$ & $\infty$ & $n$ & $\phi$ \\
\hline 1958 & XII & 15 & 6 & 40.0 & 9 & 60.0 \\
\hline \multirow{12}{*}{1959} & $I$ & 27 & 26 & 96.3 & 1 & 3.7 \\
\hline & I I & 20 & 20 & 100.0 & - & - \\
\hline & 111 & 23 & 23 & 100.0 & - & - \\
\hline & IV & 33 & 31 & 93.3 & $2^{*}$ & 6.1 \\
\hline & V & 33 & 32 & 97.0 & 1 & 3.0 \\
\hline & VI & 35 & 28 & 80.0 & 7 & 20.0 \\
\hline & YII & 22 & 17 & 77.5 & 5 & 22.7 \\
\hline & $V 111$ & 23 & 10 & 43.5 & 13 & 56.5 \\
\hline & IX & 25 & $5^{* *}$ & 20.0 & 20 & 80.0 \\
\hline & $x$ & 27 & - & - & 27 & 100.0 \\
\hline & $\mathrm{XI}$ & 26 & - & - & 26 & 100.0 \\
\hline & XI I & 26 & 8 & 30.8 & 18 & 69.2 \\
\hline \multirow{2}{*}{1960} & I & 24 & 22 & $9 i .7$ & 2 & 8.3 \\
\hline & II & 21 & 20 & 95.2 & 1 & 4.8 \\
\hline
\end{tabular}

epididymis after spermatogenesis has ceased in the testes. Spermatozoa are not observed in smears or spermatogenesis in testes in October and November, and these months therefore form a period when the gonads are in a state of complete rest.

The epididymis smear method is in principle satisfactory for the definition of the state of activity of the gonads of males, and in addition to simplifying work on the material, made it possible at once to define the fertility of the individual examined.

in the two initial phases of the reproduction season included in the investigations the first sexually active males appear in December. The ratio of the percentage of the two groups of males: sexually active and 
inactive, in the monthly samples, is shown in table 2. The percentage of sexually inactive males in December 1958 was 60, decreasing in January 1959 to 3.7 , while the analogical values for the $1959 / 60$ season were 69.2 and $8.3-4.8 \%$ of sexually inactive males being observed as late as February. During the period of activity a distinct peak is observed, indicated by the maximum dimensions of the testes, in March, and a sharply defined decrease in August. The end of the breeding season in males is noticed as late in August - September, affecting the whole population to an equal degree.

The first young animals appear in April and their number increases in the following months. They form from $6.1 \%$ in April to $56.5 \%$ in August of the total number of males. No difficulty is in principle encountered in distinguishing this group during this period. They are characterised primarily by the juvenile structure of the testes, the weight of which does not as a rule exceed 1 gramme. An analysis of body weight may supply additional data. In the case of the present material it was found that specimens with a body weight of up to about $3 \mathrm{~kg}$ never exceeded the age of 6 months at any time of the year (C a boń-R a czyńska, 1964a). The body weight of males, taking into consideration the state of sexual activity, is given in fig. 2. During the reproduction season body weight in the group of sexually inactive young males comes within an upper limit of approximately $3 \mathrm{~kg}$ and distinguishes them from the sexually active males. During the regression feriod, when the body weight was the only index of age, it is impossible completely to distinguish the young from the old hares, it being possible only to divide the group of the youngest animals, not exceeding 6 months at maximum, from the remainder. In December, when the first sexually active males appear, no spermatozoa were found in any of the specimens treated as the youngest on account of their body weight.

The moment of maturation of the young males at the start of the reproduction season was analysed in detail on an additional series of 72 males from the period from January 21st - February 2nd 1963. The age of these specimens was known and was defined by several methods (B u jalska et al., 1965). A comparison of the weights of testes (Fig. 4) shows that the males over 8 months old do not differ in the time of attainment of sexual activity from the older hares, all the animals in these two groups being sexually active (an exception to this was formed by male no. 1015, defined as an old hare with symptoms of senile regression of the testes). Distinctly smaller testes were observed in the youngest hares aged less than 8 months, one of which 


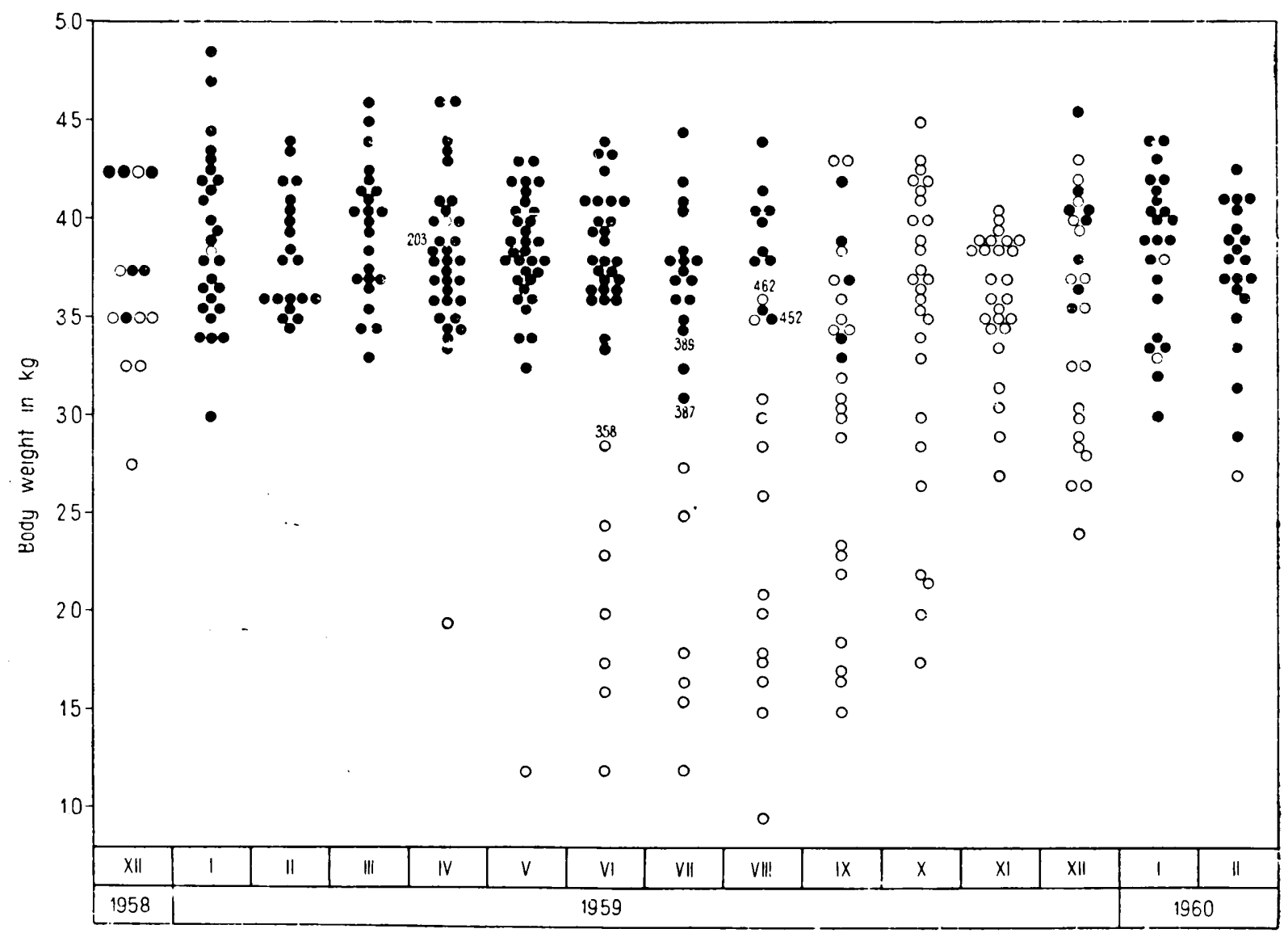

Fig. 2. Variations in the body weight of males; - spermatozoa present in epididymis; $\bigcirc-$ spermatozoa absent in epididymis.; 203 - specimens with symptoms of senile regression. 


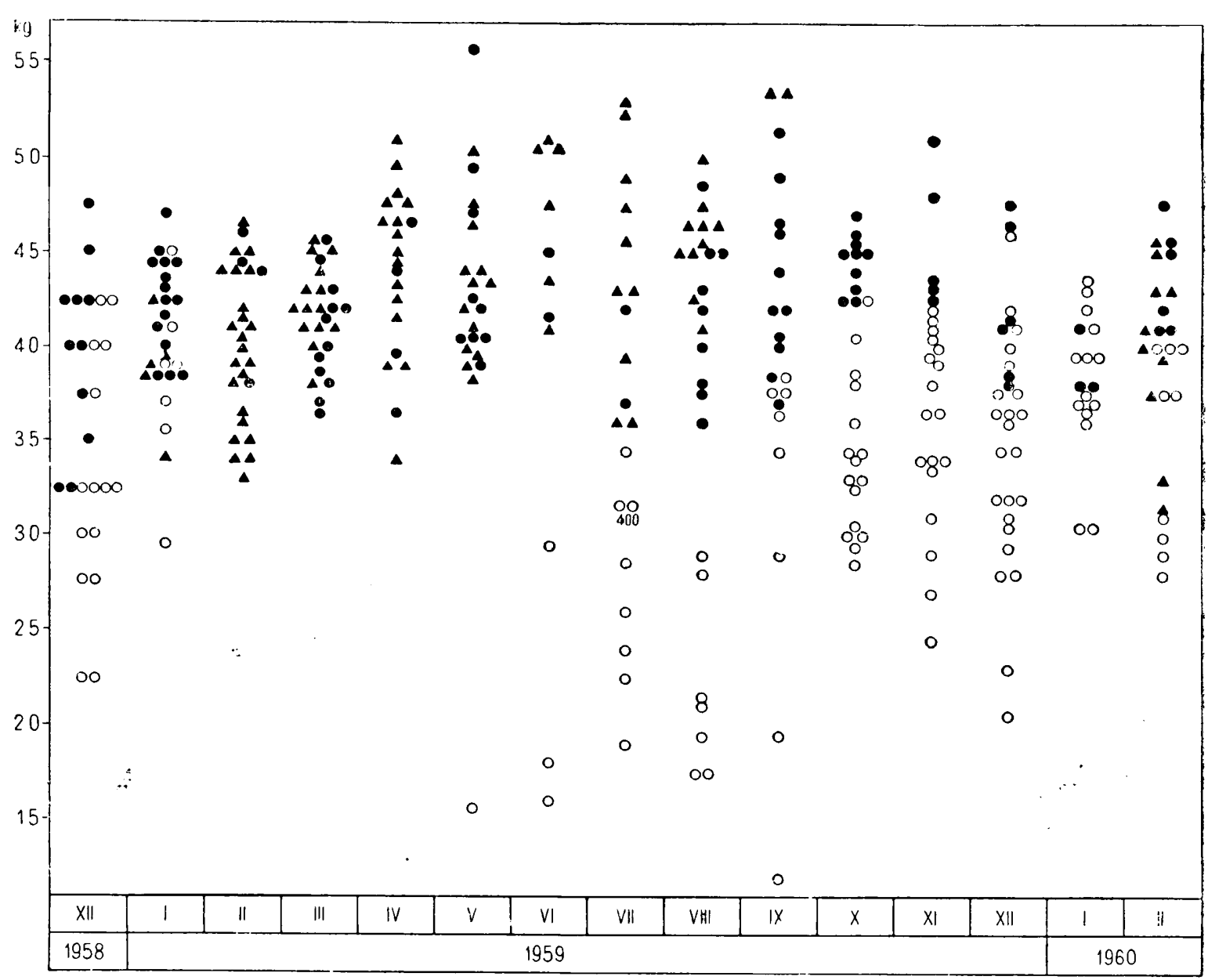

Fig. 3 Variations in the body weight of females.; $\bigcirc-$ smooth uterus; - striped uterus; $\Delta$ - pregnant females. 
was still sexually immature. This leads to the conclusion that the maturation of young males from the summer litters as a rule takes place slightly later than the renewal of the reproductive functions in old individuals. The number of sexually active males at the beginning of the reproduction season therefore depends on the age structure of the population, that is, on the percentage of the youngest group of animals. 'The sexual activity of these two groups does not balance till later on, usually during the months of January-February.

Cases of sexually inactive males at the beginning of the reproduction season may form evidence of the age necessary for the attainment of

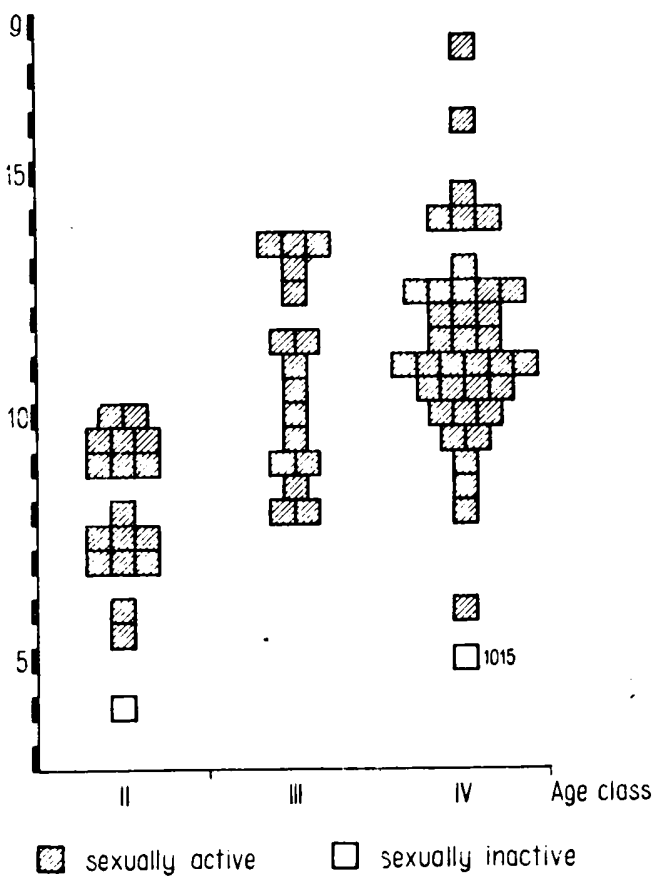

Fig. 4. Variations in the weight of the testes in age groups (during the period from January 21st - February 2nd 1963). Age class II. - about 8 months old; Age class III. 9-12 months old; Age class IV. 1 year old and over.

sexual maturity. Assuming that sexually inactive males in January and February were born at the end of the reproduction season (August September), then they attained maturity at the age of at most the 5-7 month of life. The question of the sexual maturation of young males from the first litters, during the same reproduction season, may be considered on this basis. A tendency to increase in the weight of the testes of young males is observed in specimens No. 358 and 462 (Figs. 
1 and 2). In both of these specimens, classified with the group of inactive animals on the basis of the sperm smears, the process of spermatogenesis in the testes and formation of the first spermatozoa was established histologically. It would seem that males nos. 387 and 389 from July are also young specimens, which matured during the reproductions season. Bearing in mind the fact that the first manifestations of maturation are observed as early as June, it may be taken that this phenomenon increases in intensity in July and August. During this period the oldest specimens may be about 6 months old, and with the favourable feeding conditions during the height of the growing season may be in good condition and exhibit indices of body dimensions and weight similar to those of adults. A decrease in the number of sexually inactive males, that is, males born the same year, is in addition observed in July in the distribution of the material. This phenomenon has, however, been treated as accidental and resulting from the methods used for collection of material.

As from August specimens with weights of testes below $5 \mathrm{~g}$, treated as old animals, begin to appear in the material. Histological examination revealed that male no. 452 had reached the stage of autumn regression, since the production of spermatozoa has ceased in the testes, although spermatozoa were found in the smear. On account of the lack of reliable criteria for defining the age of all the individuals, certain of the cases remained unexplained. It would however appear that regression of the testes does in fact begin as early as July.

The cases described of maturation of young males form an expression of the tendency to maturation evident in the group of the "oldest" of the animals born that year, in the well-grown hares from the relatively small first litters of the season. The phenomenon occurs in animals aged from 5-6 months, during a period when the decrease in the dimensions of the gonads in adult sexually active males, connected with the beginning of regression, becomes perceptible. Similar phenomena have been observed in populations of other mammals. In Apodemus flavicollis ( $\mathrm{Melchior}$, 1834), A d a mczew st a (1961) discovered and increase in the gonads of young males from the later litters, leading up to the first stages of spermatogenesis and interrupted by the autumn regression. In the case of the hare this process does, it is true, lead to attainment of maturity, but takes place in a relatively limited number of young males, varying each year, from the first of that year's litters. It is impossible at present to discuss the significance of this phenomenon to the population until such time as it is known whether these individuals do in fact take part in reproduction. 


\section{B. FEMALES}

\section{Size and Condition oi Reproductive System}

U terus. Use has been made in work on this material of the differences, described by Bloch \& Strauss (1958), in the external appearance of the uterus in young and old animals. These differences consist in the occurrence in old females in the external layer of the myometrium of macroscopically distinct muscular raised stripes, giving the uterus the appearance in the cross-section of being striped lengthways. This character, which is connected with previous pregnancy, does not occur in young females which have not reproduced. The material was therefore divided into two groups, using in addition for purposes of classification the measurements of the whole of the genital organs (size of ovaries, length and diameter of the horns of the uterus). The division described was compared with the body weight, and in certain of the cases, with the definitions of age of individuals made by $\mathrm{Ca}$ bon - R a czyńska (1964) and Bujalska (1964) on the basis of the ossification of the skull and pelvis. It was found that all the young females came within the group of individuals with a smooth surface to the uterine horns. On the other hand, during the interval in reproduction, part of the females, identified as young specimens on the basis of the structure of the uterus, were characterised by a skeleton structure typical of animals in the second year of their life, and thus these females must have taken part in reproduction the previous season. Specimens defined as old on the basis of the uterus, having previously been pregnant, were allocated according to comparative identifications to the group of adult specimens. On these grounds it was accepted that the principle adopted for dividing the specimens made it possible to distinguish females with striped uterine horns as adult and reproducing. In case of females in which the uterus was smooth, this character made it possible to distinguish young, sexually inactive females only during the reproduction season, since it proved to be misleading during the anoestrus period. As in the greater part of the specimens it was impossible to use other means of determining age, the division described was consistently used for the whole of the material.

Microscopic examination of the uterus (Kolos ov, 1941; B loch \& S trauss, 1958) reveals the lack of distinct differences between old and young females during the period of the anoestrus. Characteristic changes in the uterus do not occur until the period immediately preceding oestrus and during oestrus itself. Such data are of less value for determining the degree of sexual activity, the dimensions of the 
gonads and presence of corpora lutea constituting, for practical purposes, a far simpler and more reliable criterion in the case of the hare.

The dimensions of the uterine horns are smaller in young females than in sexually active ones. The maximum breadth of the uterus varies in young females from 1 to $5-6 \mathrm{~mm}$, while in sexually active specimens this measurement is from 7 to $15 \mathrm{~mm}$. During the period of the autumn anoestrus the breadth of the uterine horns in females already reproducing is greatly reduced and attains at most $10-12 \mathrm{~mm}$.

The length of the horns is a very variable dimension and in addition, as in the case of the breadth, may, on account of the structure of the organ, be subject to changes during preparation and preservation, hence the measurements given do not have an absolute value. In the preserved material the horns of the uterus in young females do not exceed in principle a length of $10 \mathrm{~cm}$. The dimensions of the genital organs in females described may form a supplementary index of their age and state of sexual activity.

Ovaries. The size of the ovaries, as in the case of the testes, depends to a great extent in the hare on the phase of sexual activity. During the yearly cycle the weight and volume of the gonads in females are subject to a distinct and similar rhythm of variations (Fig. 5). An increase in the dimensions of the ovaries began in 1959 in January. Increase in weight and size rises sharply until the time of attainment of maximum values, in March and April. The considerable differences between extreme means of weight from December and April are worthy of note (rspectively: 1.14 and $3.76 \mathrm{~g}$ ). The difference between the mean volume is even more distinct $\left(1.2\right.$ and $\left.6.8 \mathrm{~cm}^{3}\right)$. Despite the fact that intensive reproduction continues, a tendency to a decrease in the size and mass of the ovaries is markedly evident in adult females as from April. The decrease in weight takes place more or less evenly, reaching in September, when reproduction ends, a level equal to that of January. The minimum values of weight of the ovaries occurs in November and December $(0.53$ and $0.48 \mathrm{~g})$. In 1968 the rise in the curve begins in January, a distinct difference being observed in relation to the weight values from January of the previous season, to which they do not become similar until February 1960. This shift in month described corresponds to the equally delayed start of reproduction.

The young females represented in the material from May onwards are characterised by the small dimensions of their ovaries (weight below $0.3 \mathrm{~g})$. They continue to be distinctly separate in this respect until October (Fig. 6), after which the elimination of differences made it necessary to examine the two age groups jointly (Fig. 5), 
The fact that considerable individual variations in the weight of the ovaries occur must be emphasised (Fig. 6), particularly in females during the spring period. The maximum range occurs in April - from 1.05 to $6.65 \mathrm{~g}$. The maximum weight values are connected with pregnancy, since they were found in pregnant females or females which had already given birth. A relatively low weight of ovaries is simultaneously found in some of the pregnant females, decreasing, particularly

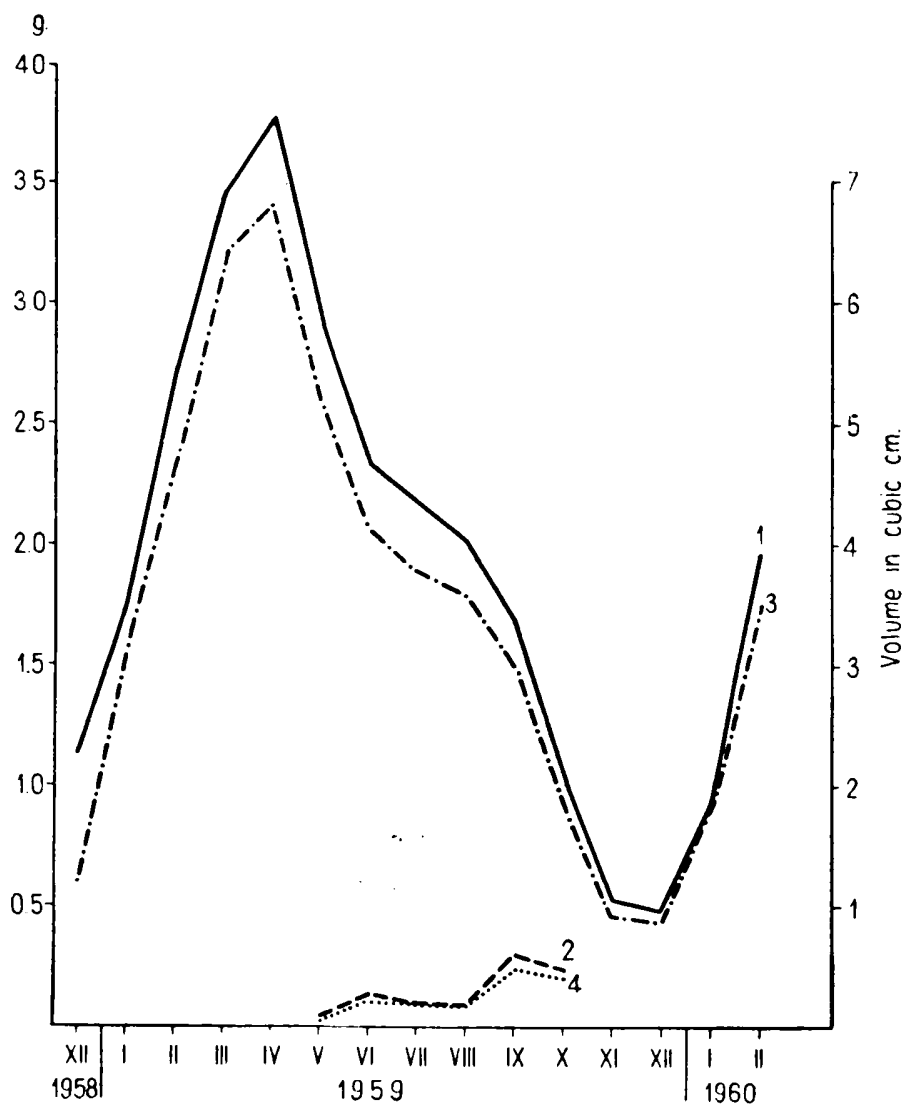

Fig. 5. Mean weight and volume of ovaries during the yearly cycle. Weight of ovaries: 1. adult females; 2. young females. Volume of ovaries: 3. adult females;

4. young females.

at the beginning and end of the reproduction period, to $1 \mathrm{~g}$ or even less. The young females are characterised during the reproduction season by slight individual variations in the weight of the gonads, ranging from 0.02 to about $0.4 \mathrm{~g}$ in August and $0.8 \mathrm{~g}$ in September. During the period of the anoestrus the range of variations for all the females narrows to values from $0.04-1.2 \mathrm{~g}$. 


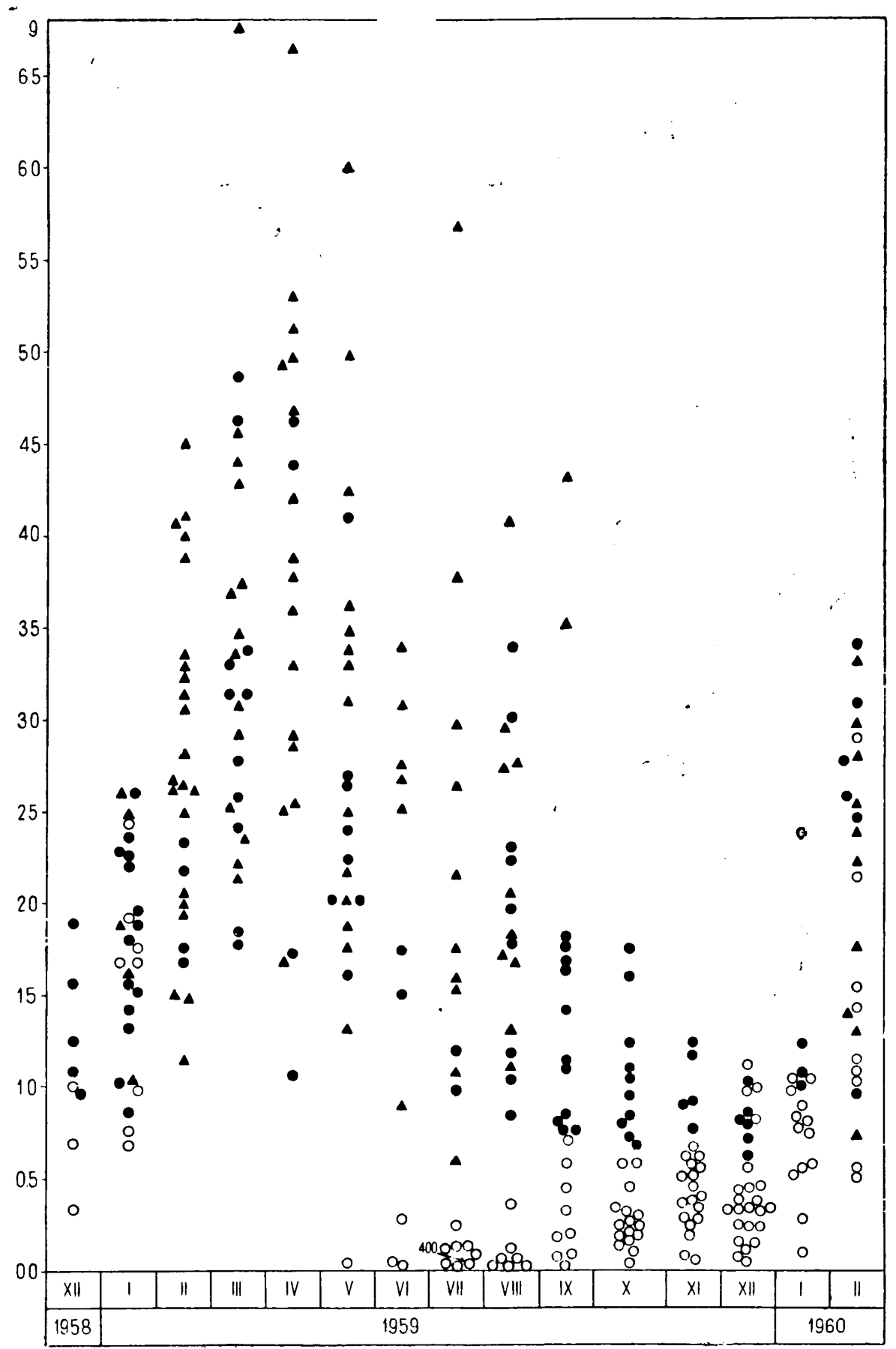

Fig. 6. Individual variations in weight of ovaries during the yearly cycle. $\bigcirc-$ smooth uterus; - striped uterus; $\mathbf{\Delta}$ - pregnant females. 
The microscopic structure of the ovary in the hare was analysed in detail by Bloch \& Strauss (1958), who found that it is possible to distinguish old females from young ones on the basis of the structure of the ovaries only in extreme cases. On account of the specific process of luteinisation of the ovaries taking place during the period preceding sexual maturation, the most reliable criterion for distinguishing young females remains the size of the organs. In the case of the present macroscopic observations it was possible to distinguish only the youngest females from the appearance of the cross-section of the gonad, in which the interior of the ovary is compactly filled witn vesicles. In older females the vesicles are visible on the periphery in the cortical layer, in the luteinised mass of the ovary. Mature Graafian follicles can be observed in the hare with the naked eye owing to their considerable dimensions $(1-1.5 \mathrm{~mm}$ diameter, Kol o s o v, 1941; Bloch \& Strauss, 1958).

The corpora lutea in the ovaries of pregnant females can be clearly distinguished and are not infrequently visible on the surface of the ovary in the form of dark prominences, or show through as darker spots. Their shape, usually round or oval - is often deformed by the presence of several corpora filling the interior of the ovary and adhering to each other. In one case corpora lutea about $10 \mathrm{~mm}$ in diameter were observed in the form of an emission from the ovary joined only by a narrow tongue to its mass. The size of corpora lutea in the hare (diameter $4-13 \mathrm{~mm}$ usually about $9 \mathrm{~mm}$ ) makes it easy to count them with the naked eye. The size of corpora lutea is not subject to distinct variations during the post-implanation period of the stages of the embryonic development. Quite frequently at the beginning of a new pregnancy the corpora from the preceding pregnancy are still visible, but as a rule they have reached the stage of atrophy and are only weakly distinguishable from the tissue of the ovary. After the reproduction period has ended there are faintly perceptible traces of corpora lutea in the gonads as late as October. It is difficult to define exactly the time during which corpora lutea remain in the ovary on the basis of macroscopic observations. It would, however, seem somewhat improbable that towards the end of the reproduction season on the basis of the remaining traces of corpora lutea, the number of ovulated eggs could be determined for each litter as $\mathrm{Pierevalov}$ (1956) did in the case of $L$. tibetanus. Bloch \& Strauss (1958) say nothing about any such possibility in the case of $L$. europaeus, while $\mathrm{Rey-}$ nolds \& Stinson (1959) state that it is only possible to diagnose the first pregnancy in the season on the basis of examination of 
the ovaries. In the present investigations in each case only one generation of corpora lutea found in the ovaries has been taken into consideration.

\section{Table 3.}

Sexual activity of adult females.

* - exlusively preimplantation stages, early implantation or mortallty in the initial period of pregnancy; ${ }^{* *}$ - lactating females.

\begin{tabular}{|c|c|c|c|c|c|c|c|}
\hline \multirow[b]{2}{*}{ Year } & \multirow{2}{*}{\multicolumn{2}{|c|}{ Honth. }} & \multirow{2}{*}{$\begin{array}{l}\text { No. of pregnant } \\
\text { Eemales w1th embryos }\end{array}$} & \multirow{2}{*}{$\begin{array}{l}\text { No embryos present, } \\
\text { corpora lutea } \\
\text { present }\end{array}$} & \multicolumn{3}{|c|}{ Number of: } \\
\hline & & & & & $\begin{array}{l}\text { Sexually } \\
\text { active }\end{array}$ & $\begin{array}{l}\text { Sexually } \\
\text { inactive }\end{array}$ & $\begin{array}{l}\text { Adult } \\
\text { Eemales }\end{array}$ \\
\hline \multirow[b]{2}{*}{1958} & \multirow[b]{2}{*}{$X I I$} & $n$ & - & - & - & 17 & 17 \\
\hline & & $\approx$ & - & - & - & 100 & 100 \\
\hline \multirow{24}{*}{1959} & \multirow[b]{2}{*}{1} & $n$ & 5 & $q^{*}$ & 7 & 18 & 25 \\
\hline & & \% & 20.0 & 8.0 & 28.0 & 72.0 & 100 \\
\hline & \multirow{3}{*}{ II } & $\mathrm{n}$ & 23 & $y^{*}$ & 26 & 1 & 27 \\
\hline & & क & 85.2 & 11.9 & 96.3 & 3.7 & 100 \\
\hline & & $\mathrm{n}$ & 14 & 12 & 26 & - & 26 \\
\hline & III & $\varnothing$ & 53.8 & 46.2 & 100 & - & 100 \\
\hline & \multirow{2}{*}{ IV } & $n$ & 15 & 5 & 20 & - & 20 \\
\hline & & $D$ & 75.0 & 25.0 & 100 & - & 100 \\
\hline & \multirow{2}{*}{$v$} & $\mathrm{n}$ & 13 & 9 & 22 & - & 22 \\
\hline & & क & 59.1 & 40.9 & 100 & - & 100 \\
\hline & \multirow[b]{2}{*}{ VI } & $n$ & 6 & 2 & 8 & - & 8 \\
\hline & & $\%$ & 75.0 & 25.0 & 100 & - & 100 \\
\hline & \multirow{2}{*}{ VII } & $n$ & 10 & 1 & 11 & 1 & 12 \\
\hline & & क & 83.3 & 8.3 & 91.6 & 8.3 & 100 \\
\hline & \multirow{2}{*}{ VIIII } & $\mathrm{n}$ & 10 & 5 & 15 & 4 & 19 \\
\hline & & $\varnothing$ & 32.6 & 26.3 & 78.9 & 24.1 & 100 \\
\hline & \multirow{2}{*}{ IX } & $\mathrm{n}$ & 2 & - & 2 & 10 & 12 \\
\hline & & \% & 16.7 & - & 16.7 & 83.3 & 100 \\
\hline & \multirow{3}{*}{$x$} & $n$ & - & - & $2^{* *}$ & 14 & 16 \\
\hline & & $\$$ & - & - & 12.5 & 37.5 & 100 \\
\hline & & $\mathrm{n}$ & - & - & - & 13 & 13 \\
\hline & $X I$ & क & - & - & - & 100 & 100 \\
\hline & \multirow{2}{*}{ XII } & $\mathrm{n}$ & - & - & - & 12 & 12 \\
\hline & & \% & - & - & - & 100 & 100 \\
\hline \multirow{4}{*}{1960} & & $n$ & - & - & - & 15 & 15 \\
\hline & & क & - & - & - & 100 & 100 \\
\hline & & $\mathrm{n}$ & 9 & $5^{*}$ & 16 & 9 & 25 \\
\hline & & $\%$ & 44.0 & 20.0 & 64.0 & 36.0 & 100 \\
\hline
\end{tabular}

2. Participation of Females in Reproduction

In considerations of the problem of the part played by females in reproduction, the presence of corpora lutea was taken as a basis when estimating their reproductive function. Females clearly pregnant or in the early implantation and preimplantation stages were treated together with specimens in which the presence of corpora lutea corresponding to the postparturition stage was established, as reproducing and sexually active. Material arranged in this way is given in table 3 according to months. The group of sexually inactive females is represented here at the beginning of the season by females which are not as yet 
taking part in reproduction, and at the end by individuals which have ceased reproduction. The numbers of pregnant females given in table 3 are greater than those given for the same material by $\mathrm{Pielowski}$ (1962), due to the earlier stages of pregnancy have been taken into account in the present study. Additional differences result from the fact that I calculated the percentage of pregnant females not from the total number of females in a month, but only in relation to adult females.

The reproduction season began in the case of females in January in 1959. In the second half of January pregnant females formed $20 \%$ of the total number of females and in February this percentage rose to $85 \%$. During this period all the females were treated as sexually mature, and in later months the young specimens born that year were excluded from this group. It must be emphasised that as early as $\mathrm{Fe}-$ bruary the females exhibit features of complete sexual activity (increase in the measurements of the uterus and gonads, presence in the ovaries of distinct Grafian follicles). Of the 27 females from Februa$\mathrm{ry}$, it is only in one specimen that there are no corpora lutea in the ovaries, in 23 embryos were found and the remaining 3 have corpora lutea indicating the early stages of implantation. It may therefore be stated that as from February of that year the whole of the females took part in reproduction. In March, despite the decrease in the number of pregnant females $(54 \%)$ all the specimens had corpora lutea. The succeeding period of intensity of pregnancies occurred in April and coincided with the moment at which the maximum dimensions of the gonads were attained. After the peak in June-July which followed, as from August a sharp decrease is observed in the number of pregnant females. Simultaneously interruption of the reproduction functions is observed in part of the females (in August about $20 \%$ ). Final pregnancies were noted in mid-September: embryos well advanced in development were found in two females, while 6 females were still lactating It is worthy of note that as late as October 19th 1959 one lactating female which had well-developed milk glands and traces of corpora lutea in the ovaries was found in the material. The following year females with developed corpora lutea and, embryos appeared for the first time in mid-February, forming over $60 \%$ of the total number. The interval in reproduction therefore lasted from October to February of the following year.

Observations of the maturation of young females in the two study seasons show that whereas the last large litter was born at the end of August 1959 (possible reproduction in September), some of the females 
were not participating in reproduction as late as February of the following year. Analysis of the body weight of females (Fig. 3) shows that as in the case of males the youngest specimens (the lightest in weight) begin to reproduce later (e.g. females weighing up to $3 \mathrm{~kg}$ from February 1960 and the specimen from January 1959). During this period pregnant females are distributed in the greatest numbers near values of approximately $4 \mathrm{~kg}$ (the early stages of embryonic development do not cause an increase in the body weight of females at that time).

The lack of identification of age for the whole material made it impossible to solve the problem of sexual maturation and participation in reproduction of females during the first calendar year of their lives. In Polish wildlife literature the conviction is general that the so-called "March hares", that is hares from the first litters in the season, can reproduce the same year (K r a w c z yn ski, 1924; $\mathrm{H}$ abe r \& $\mathrm{Nunberg}$, 1956). The case of reproduction in a young female, described by Valentincic (1961) from Yugoslavia can be taken as completely certain. On account of the considerable geographical differences in relation to Poland, it is quite possibly an objective fact that no young reproducing females were found in the study material among specimens, the age of which was established on the basis of the structure of the skull and pelvis. The existence of a certain tendency to sexual maturation is, however, borne out by the presence in one case of a distinct corpus luteum $3 \mathrm{~mm}$ in diameter, in female no. 400 from July 1959, the structure of the whole of the genital organs being typically juvenile. A tendency to increase in the size of the ovaries can be observed in young females in September. On these grounds it may be taken that young females do not maturate until the following calendar year, at a minimum age of 7 months.

\section{COMPARISON OF THE SEXUAL ACTIVITY CYCLES OF MALES AND FEMALES}

At the beginning of both the reproduction seasons studied differences were found between males and females in the time at which they attain sexual activity. The first sexually active males appear in December, while the first pregnant females occurred in January 1959 and in February 1960, that is, $1-2$ months later in relation to the males which had already reached the oestrus period. The time of reproduction in the case of females must therefore depend on the degree of readiness for reproduction, since in view of the activity of the males the possibility of the females being fertiliscd was a real one as early as, for instance, in December 1959. Their readiness for reproduction 
may be defined with great accuracy on the basis of the weight of the gonads. The progression of the testes in males began in December in both study seasons. The analogical phenomenon of the increase in the dimensions of the ovaries is not observed until January. The mean weight of the gonads attains a maximum in March in the case of males, whereas in females it occurs a month later, in April.

The end of the reproduction season is evident first in males, with the beginning of regression of the gonads and disappearance of spermatogenesis. In September, when spermatogenesis was no longer observed in males, pregnancy continued in some of the females. In this way the interval in reproduction in extreme cases lasts in both sexes for an approximately equal time, and differs only as to the beginning and end of activity.

It will be seen from the comparison given above that if the start of reproduction of a population defines the readiness of the females for breeding (a certain number of males capable of mating always occurring at this time), then the disappearance of spermatogenesis in males precedes the cessation of the sexual activity of females at the end of the reproduction season.

Despite distinct differences between the beginnings of the reproduction seasons studied, the oestrus occurred in males at the same time. This indicates that the time at which males begin sexual activity is more stable in time than in females. The maximum weight of the testes also occurs fairly regularly in March (S t i e v e, 1952; R i e c k, 1956; S c a r la te s cu et al., 1963).

Sexual maturation of young hares takes a different course in the two sexes. The young males attain sexual maturity in the following season a month earlier than the young females. It would seem that these differences have some connection with the general delay in the readiness of females for reproduction at the beginning of the new season.

\section{EFFICIENCY OF REPRODUCTION}

\section{Level of Ovulation}

The number of ova ovulated was defined indirectly by means of counting the number of corpora lutea, taking into consideration only one generation of corpora corresponding to the current pregnancy. It was decided not to include the number of corpora lutea in females which had no embryos in the uterus, on account of the difficulties in defining the preimplantation and early implantation stages. The results 
obtained are given in Fig. 7 calculated for 1 pregnant female. Three distinct periods are found in the formation of the level of ovulation over the whole reproduction season. The first of these periods, from January to April, is characterised by even but sudden increase in the number of ovulated eggs in reproducing females, rising from 1 in Ja-

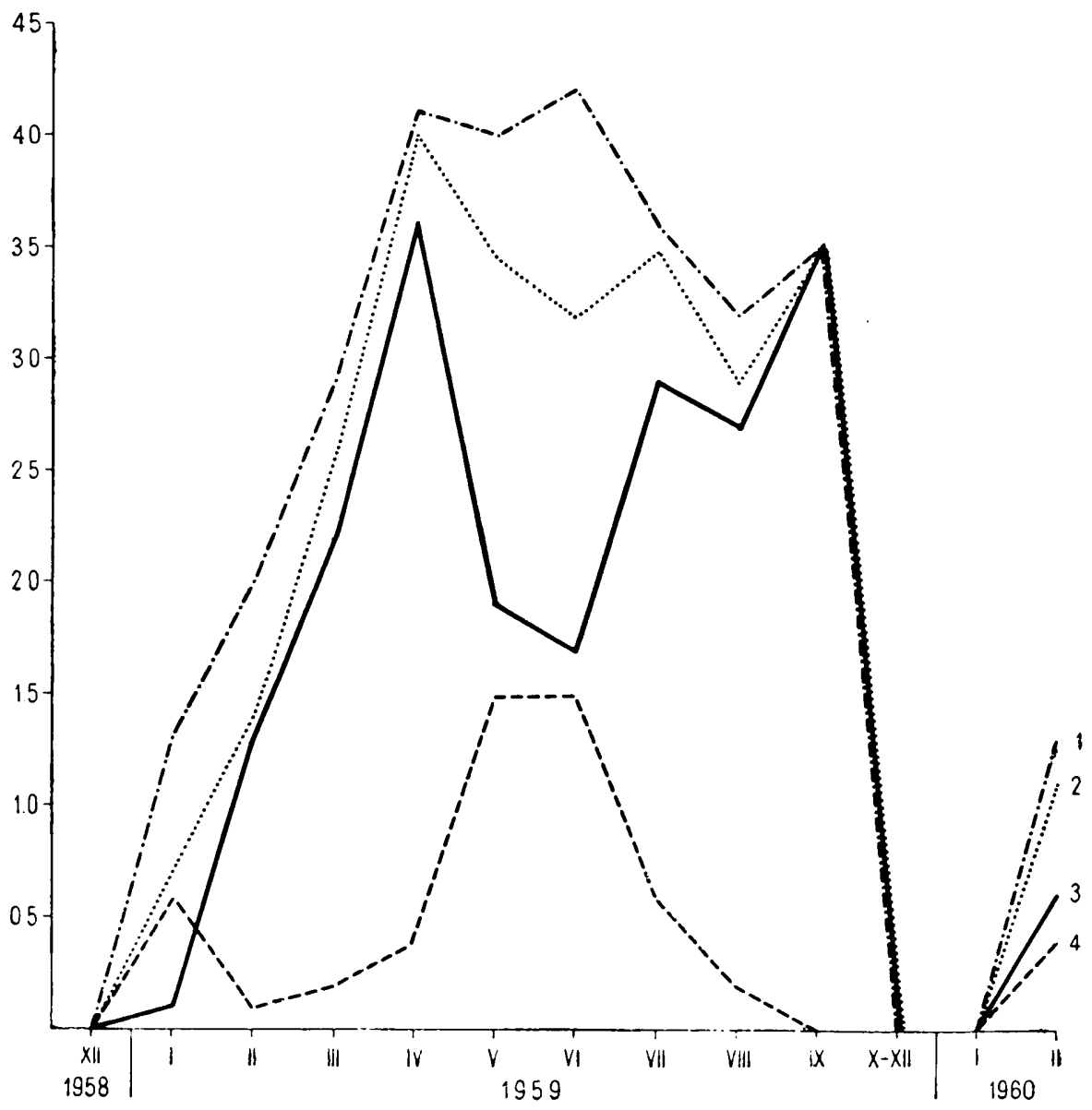

Fig. 7. Formation of the mean size of litter in different months of the reproduction season. 1. ovulation level; 2. implantation level; 3 . mean size of litter; 4. resorption level.

nuary to an average of 4 per female in April. The second period occurs during April-June, when ovulation is maintained on an evenly high level (mean about 4). As from July there is a decrease in ovulation to a value of 3.2 in August. This latter period is remarkable, since it is generally known that there is a decrease in the number of young per 
litter in the autumn, analogical to the relations observed in the spring (Kolos ov \& B k e ev, 1947; R i e ck, 1956 and others). On the basis of the present results it can only be said that there is a tendency to decrease in the number of eggs ovulated, beginning in June. No such degree of decrease is observed, however, as that occurring at the be. ginning of the season.

A maximum of 6 corpora lutea were observed in 6 females from May and June in our material.

The level of ovulation may be treated as an index of the reproduction potential of the females, defining the maximum linits of the numbers

Table 4.

Variations in implantation over the yearly cycle.

\begin{tabular}{|c|c|c|c|c|c|c|c|c|c|}
\hline \multirow{2}{*}{ Year } & \multirow{2}{*}{ Bonth } & \multicolumn{6}{|c|}{ Number of implanted embryos } & \multirow{2}{*}{$\begin{array}{l}\text { Number of } \\
\text { pregnant } \\
\text { females }\end{array}$} & \multirow{2}{*}{$\bar{x}$} \\
\hline & & 1 & 2 & 3 & 4 & 5 & Total & & \\
\hline 1958 & $\mathrm{XII}$ & & & & & & & & \\
\hline \multirow{10}{*}{1959} & $I$ & 5 & & & & & 5 & 5 & 1.00 \\
\hline & I I & 1) & 10 & & & & 33 & 23 & 1.43 \\
\hline & I I I & 2 & 3 & 7 & 2 & & 37 & 14 & 2.64 \\
\hline & IV & & & 3 & 9 & 3 & 60 & 15 & 4.00 \\
\hline & $\mathrm{v}$ & & 3 & 3 & 5 & 2 & 45 & 13 & 3.46 \\
\hline & VI & & 1 & 3 & 2 & & 19 & 6 & 3.17 \\
\hline & $\because I I$ & 1 & 1 & 2 & 4 & 2 & 35 & 10 & 3.50 \\
\hline & VIII & & 3 & 5 & 2 & & 29 & 10 & 2.90 \\
\hline & $\begin{array}{c}I X \\
X-X I I\end{array}$ & & & 1 & 1 & & 7 & 2 & 3.50 \\
\hline & Total & 21 & 21 & 24 & 25 & 7 & 270 & 98 & $2.76^{\circ}$ \\
\hline \multirow[t]{2}{*}{1960} & I & & & & & & & & \\
\hline & II & 6 & 4 & 1 & & & 17 & 11 & 1.55 \\
\hline
\end{tabular}

in each litter. This potential is, therefore, only limited in the initial period of reproduction, then becomes established on a relatively high level (usually over 3.5 ovulated eggs on an average per female) until the end of the reproduction season.

\section{Level of Implantation}

The distribution of the number of implanted embryos over the yearly cycle is set out in table 4 . This table includes all the early postimplantation stages capable of being established macroscopically when dissecting the uterus.

In January and February $19591-2$ embryo pregnancies only occur, females with 3 or 4 embryos appearing from March onwards. The greatest number of embryos occurs in April (3-5 embryo pregnancies only). The mean value for this month is also the greatest (4.0 embryos 
per female). The summer and autumn periods are also characterised by a high mean value, the last pregnant females in September having $3-4$ embryos. The relations observed in the first month of reproduction of the following season differ. in February 1960 the number of embryos comes within limits of $1-3$ from the beginning, although single-embryo pregnancies predominate. There is, therefore analogy with February 1959.

The maximum number of embryos found in one female was 5 (Tab. 4). The mean value of implantation for the whole reproduction season (1959) is 2.76 per female.

\section{Embryonic Mortality}

The mortality among embryos during the period of foetal development defines the numbers of the litters born in relation to the number of ovulated eggs. Other factors limiting reproduction, such as a failure to fertilise ovulated eggs and abortions, may also play a part here, but these questions cannot be dealt with in the present material.

\section{a. Mortality before implantation}

Mortality before implantation means the failure of the eggs and blastocysts to survive, and is defined by the difference between the number of corpora lutea and the number of implantation sites (Alle $\mathrm{n}$ et al. 1947; Brambell \& Mills, 1947). In the present investigations mortality among embryos before implantation was defined less accurately by means of calculating the difference between the number of ovulated eggs (equal to the number of corpora lutea) and the number of implanted embryos. As exact microscopic observations were not made the term "pre-implantation mortality" is in this case additionally inexact. Errors might have occurred as the result of overlooking the early stages of implantation, when the foetal thickening on the uterus is not as yet perceptible and the embryo cannot be distinctly seen with the naked eye, and in addition, in the case of the greatly advanced stages of pregnancy taken into consideration. In such cases it would be possible to take into account the total (completed) resorption of implanted embryos occurring in the early stages of their development. For these reasons the term used must be taken to mean only the part of the total early embryonic mortality distinguished.

Preimplantation mortality is expressed in Fig. 7 by the difference between ovulation and implantation levels. On account of the occurr- 
ence of single-embryo pregnancies in January and their predominance in February, the basis for calculations in both seasons for these months was formed by the total number of females with large corpora lutea and not, as in the remaining months, only the females with foeti in the uterus. This was possible owing to the fact that only females pregnant for the first time occur during this period. Well-developed corpora lutea, with simultaneous absence of embryos, then indicate total mortality of litters. Over the yearly cycle this mortality is observed to intensify at the beginning and in the middle of the reproduction season. The lowest mortality occurs in March and April and at the end of the reproduction season. The smallest number of eggs develop in January and February (55-68\%) and in June $(76 \%)$.

It must be emphasised that the relatively scanty material formed by pregnant females, particularly in the initial period of reproduction, prevents more definite conclusions being reached as to the influence of the above mortality on the effects of reproduction, nevertheless it would seem that in critical periods, when general mortality of embryos increases, this factor plays an important part.

\section{b. Resorption of embryos}

Embryos in the resorption stage can be recognised macroscopically after opening the foetal chamber of the uterus. Contrary to the normally developing embryos, their structure indicates the progressive process of atrophy and decomposition, leading in extreme cases to shapeless tissue detritus remaining in the uterine horn.

The majority of the cases of resorption are observed when the diameter of the foetal thickening is $20-40 \mathrm{~mm}$ (maximum $50 \mathrm{~mm}$ ). In cases in which embryos undergoing resorption are present in the uterus in addition to normal embryos, these latter were most often from $10-20$ $\mathrm{mm}$ in length. Only once was a case found in which an embryo in the resorption stage was present together with developed embryos already covered with hair. Resorption therefore takes place as a rule in the early stages of embryonic development and identifiable traces of its occurrence probably disappear fairly rapidly. Therefore in the later periods of pregnancy, in cases of disagreement between the number of corpora lutea and number of embryos, it is not possible to define the kind of mortality of the embryos. On this account only those cases in which foeti were observed in the resorption stage in the uterus, or distinct traces of its occurrence, were used in the estimation of the intensity of resorption. In a certain number of cases, particularly at 
the beginning of the reproduction season, it is necessary to take into consideration the possibility of reduction in results due to the occurrence of a large number of the early stages of pregnancy, making the probability of occurrence of resorption in the later period of development of the embryos very considerable.

In the material used in this study the effect of resorption of the foeti on the size of the litter is considerable. Resorption causes reduction in the size of the litter during the period of the first pregnancies of the reproduction season leading to the almost total inhibition of reproduction (in January about $80 \%$ of the implanted embryos undergo resorption). Later intensity of resorption decreases and remains at a low level from February to April (6-10\% embryos implanted). A second intensification of resorption is observed in the summer, attaining a maximum in May and June. In relation to the number of embryos implanted, respectively 44 and $47 \%$ undergo resorption in these months. As from July the effect of resorption is again reduced.

During the period of the greatest intensity of resorption in the summer cases of resorption of the whole litter were several times observed in females with multiparous pregnancy. There were 4 such cases in May (resorption of 3-5 embryos), 3 in June (2, 3 and 4 embryos) and 1 in July (2 embryos).

The two kinds of embryonic mortality discussed here cause the total mortality in the prenatal period. As the result of the intensive action of these two factors $90 \%$ of the embryos in first pregnancies may die, leading to almost complete cessation of reproducion. The reduction in the number of embryos in relation to ovulation level is shown in percentages in figure 8 . During the next period of intensive mortality (May, June), over half the embryos die. Total mortality exhibits a tendency to disappear in the autumn.

\section{Size of Litter}

Formation of the size of litters takes place in close connection with the variations in ovulation and mortality levels at different periods of reproduction. The earliest period of reproduction in January 1959 most certainly had no real effect on population increase. This was due to the low ovulation level and maximum intensity of embryonic mortality, reducing litters by $90 \%$. It was not until February that it was possible to count on the continuation of pregnancies up to birth, and even so they were reduced by half and produce an average of on young hare only from each pregnant female, these young forming the generation known as "March-hares". 
Increase in the size of the litter does not take place until the March and April pregnancies. The number of embryos developing during this period is on an average from 2 to 3.5 , with minimum mortality (below $20 \%)$. This is accompanied by a high ovulation level (3-4 ova per female). The greatest number of young hares, born in April and May, come from this period.

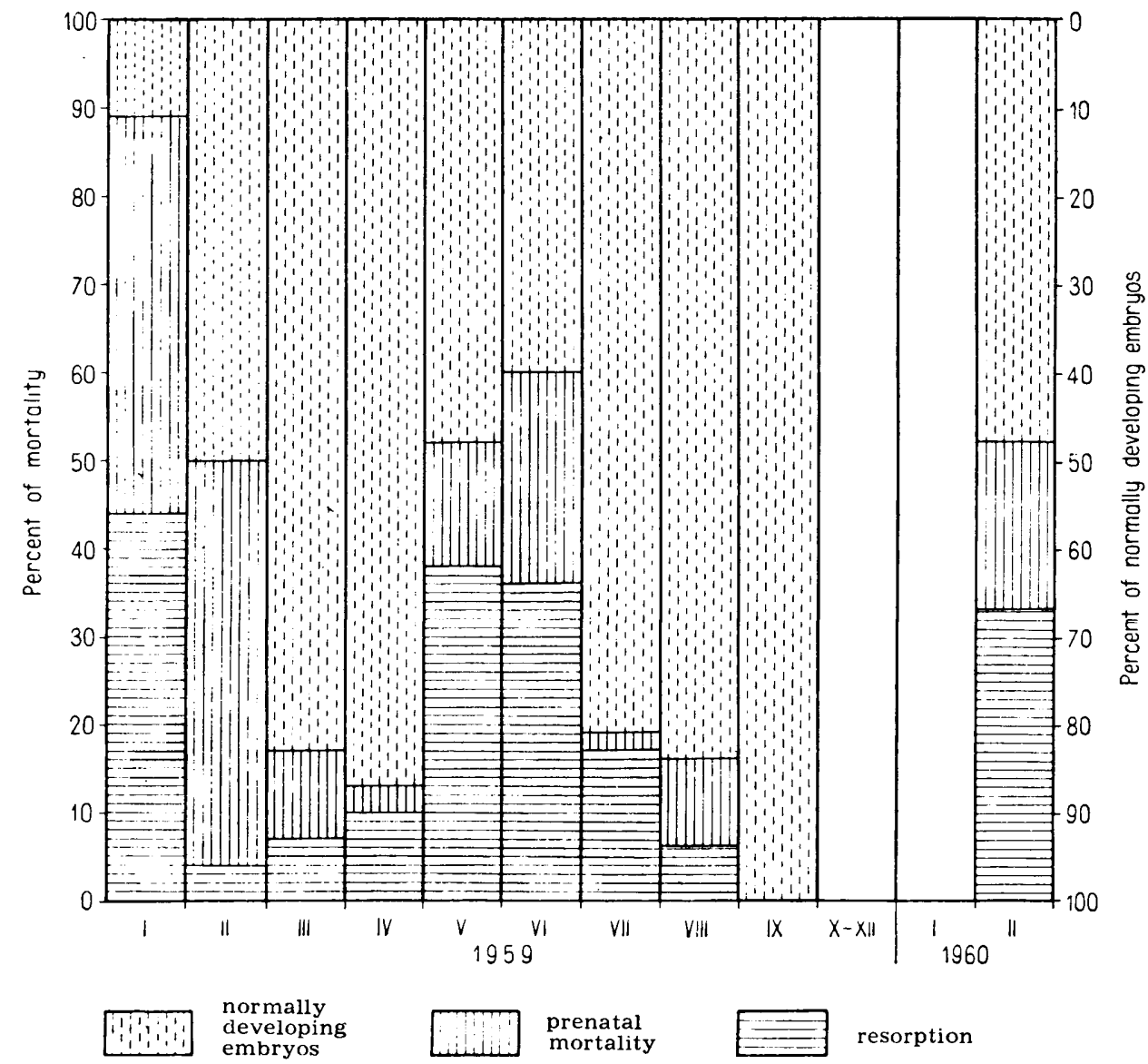

Fig. 8. Influence of embryonic mortality on the size of litters. (Ovulation level $=100 \%$.

During the summer when ovulation level attains its maximum value, mortality simultaneously increases, causing the death of over $50 \%$ of the eggs and embryos. As a result the numbers in the litters are reduced to a mean figure of approximately 2 per female, causing low reproduction efficiency in the summer (June, July). 
The autumn reproduction period is characterised by an increase in the mean number of young born as the result of a reduction in embryonic mortality. The final litters born in August and September contain on an average 3 young each, due to the high ovulation level during this period. Efficiency of reproduction decreases, however, during this period on account of the decreasing percentage of females participating in reproduction.

From the above it can be seen that the spring reproduction period, and strictly speaking the litters from pregnancies occurring in March and April, is the most imfortant for population increase. During this

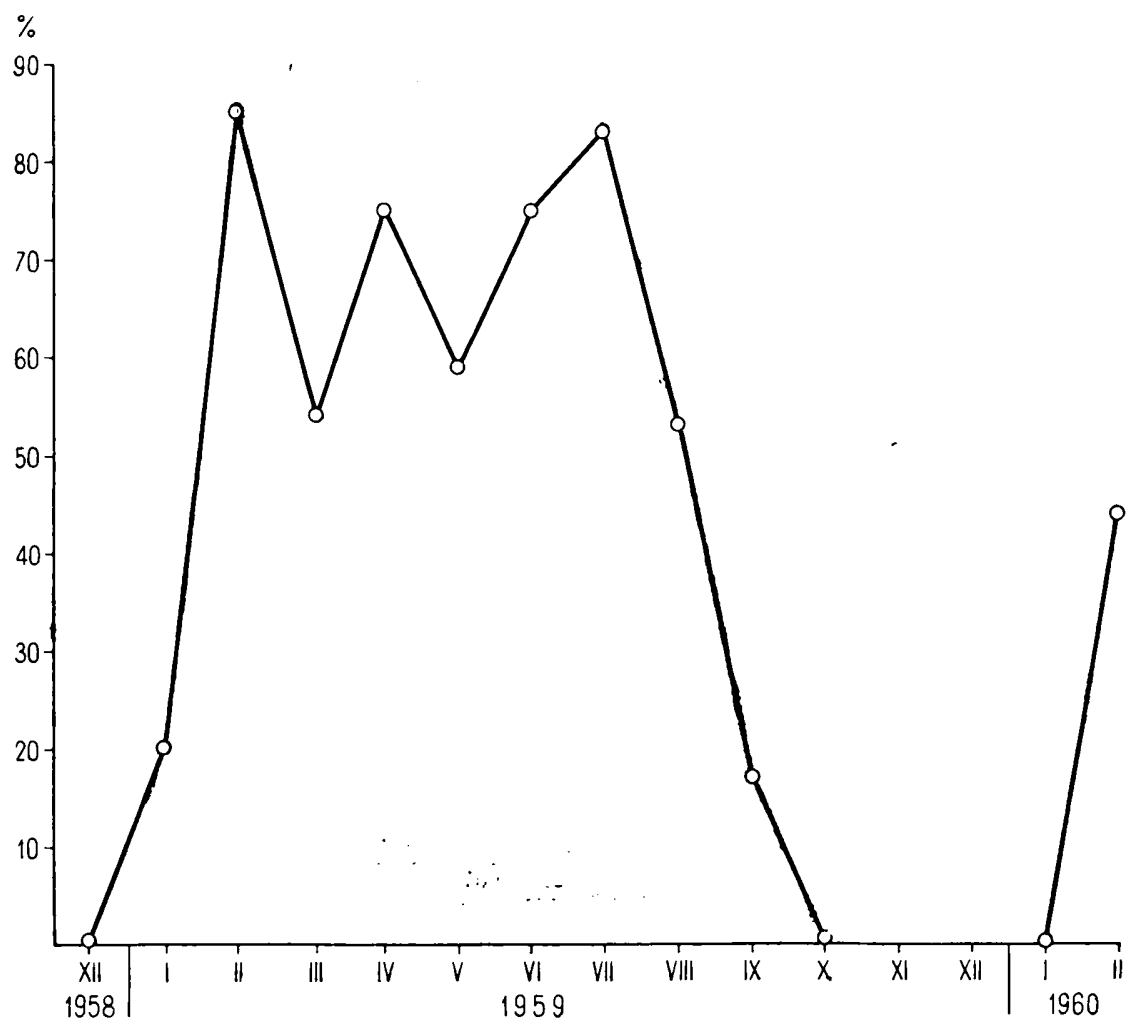

Fig. 9. Percentage of pregnant females in each months.

period the greatest percentage of embryos develop normally, which in consequence results in the largest litters being born in April and May. It is interesting to compare here the curve of intensivity of reproductjon with the curve of size of ovaries (Figs. 5 and 7). It may be assumed that the cycle of variations in the ovaries, defined in its course and 
apparently fairly stable in time, determines to a certain extent the efficiency of reproduction.

\section{Number of Litters in One Year}

It is possible to draw conclusions as to the number of litters in a reproduction season in the case of the hare only indirectly, taking the pregnancy capacity of the females and the appearance of young hares in the study area as bases. The number of pregnant females in the monthly samples (Fig. 9) has been taken as the basis for establishing the number of litters for the study period covered by the present paper. Of the females participating in reproduction the highest percentage of pregnant females occurs in February $(85 \%)$, April $(75 \%)$ and June and July (75 and $83 \%$ ). January and September may be omitted when considering this question, since the first pregnancies are not as a rule continued up to birth, while the last pregnancies occur only in a minimum number of females. On the basis of these data it would seem that there are sufficient grounds for accepting the following basic distribution of reproduction: first litter (pregnancy from February) occurring in March-April, the second (pregnancy from April) — in May-June, and the third in July-August.

The relations described are only approximate, since reproduction begins at different times in different individuals. In addition the different duration of intervals between litters results in the pregnancy capacity of females overlapping in time in a population. The intensifications in pregnancies observed form only a certain resultant of this process. Analysis of the material also reveals that reproduction rate is more intense during the spring, a fact also observed by other authors ( $\mathrm{St}$ i e$\mathrm{ve}, 1952 ; \mathrm{R} \mathrm{i} \mathrm{e} \mathrm{ck,} \mathrm{1956).} \mathrm{In} \mathrm{this} \mathrm{way} \mathrm{it} \mathrm{is} \mathrm{possible} \mathrm{to} \mathrm{explain} \mathrm{the}$ rapid succession of the first two litters occuring in March and May, as opposed to the third which is more spread out in time. While the start of reproduction can be accurately established in relation to the whole of the mature females on the basis of an analysis of the conditions of the gonads, later on observations of corpora lutea with simultaneous absence of pregnancy do not permit of determining the reproduction rate and duration of the interval between pregnancies. The females occurring in July and August in the material, in which no distinct corpora lutea were found, were most probably passing through a phase of longer intervals between pregnancies, or had even ended participation in reproduction.

In view of the fact that little advanced stages of embryonic development occur in considerable numbers in August, while single cases of 
pregnant females are found as late as September, it must be assumed that some of the females may be pregnant for the fourth time at the end of the reproduction season.

\section{Numerical Increase of Young Animals}

The numerical increase of young hares in a population, as the final result of reproduction, is of considerable importance in wildlife management practice. The number of young born during the whole reproduction season can be estimated only on the basis of an established figure for the mean number of young produced by one female during the season.

Views held by different authors on the subject of the yearly increase of young hares are in general similar. It was only in the last century that hunters were of the opinion that increase was from 15-16 (K oe $\mathrm{n}$ e $\mathrm{n}, 1954$; $\mathrm{R}$ i e c k, 1956). In the more recent investigations made by Kolosov \& Bake e (1947) it is stated, in relation to the pre-Caucasus region, that the mean number per litter is 2.5 young per female and define yearly increase for a total of four litters as 10 young. $V$ ale $\mathrm{tincic}(1955)$ found an average of 2.3 embryos per one pregnant female. Assuming that $3 / 4$ of these females produce 4 litters and $1 / 4$ three litters, then this gives a yearly total of 7.8 young per one female ( $\mathrm{R} \mathrm{i} \mathrm{e} \mathrm{ck,} \mathrm{1956).} \mathrm{According} \mathrm{to} \mathrm{R}$ i e ck (J.c.), in relation to Germany, assuming an average of $2-3$ young, there is a possibility of obtaining as many as 11 young from one female per year, if $4-5$ litters are born under favourable conditions. Reynolds \& Stins o $n$ (1959) calculated increase in the hare population of Canada on the hasis of the mean numbers in three litters $(I-1.6, I I-3.8, I I I-3.8)$, giving 9 young as the mean annual number. Scarlatescu et al. (1963) give the number as 8 young annually for Rumania.

The calculations given of increase in numbers of young hares do not take into account the phenomenon of mortality of embryos in the early stages of development or in some cases the percentage of females pregnant in successive months of the reproduction season. In the case of the present material it was shown that resorption has a significant effect on formation of the size of litters. The basis for calculations was formed by the number of continued pregnancies and the percentage of pregnant females in relation to sexually mature animals, during the period from February to August inclusively (omitting January and September). Calculation was made in the same way as that used by $\mathrm{Schwartz}$ (1942) for assessing the increase of Sylvilaqus floridanus (Alle $\mathrm{n}$, 1890). The mean number of young hares (deducting resorpt- 
ion) for one female was 2.3 (209 embryos in normal development and 91 pregnant females). During the seven-month period only $68 \%$ of the females among those sexually mature take part in reproduction. In referring this result to the relations in a population it is necessary to remember the occurrence of intervals between litters bred from one female. For the purpose of the calculations it is necessary to assume a maximum possible number of litters during the season. This number is 5 litters ( 7 months - i.e. about 210 days, assuming that pregnancy lasts 42 days). This theoretical number of litters from one femalc makes it possible to obtain a result approximately close to the real one, if the percentage of pregnant females in a population is borne mind. From this calculation $(0.68 \times 5)$ a mean figure of 3.4 litters per female during the season is obtained. With a mean number of young per litter of 2.3, the theoretical increase from one adult female during the season is 7.82 young

L e ch le it ne r (1959) in calculating the increase of young in Lepus californicus ( $\mathrm{Gray}, 1837$ ) draws attention to the embryonic mortality of whole litters. He accepts in theory that the time necessary for the same female to become pregnant again is equal in such a case to half the duration of a full term of pregnancy. Using the calculation method adopted by Lechleitner (1959), a reduction of the theoretical number of litters to 4.7 per season was obtained for the present material (allowing for the death of about $12 \%$ of whole litters). Taking into account the percentage of pregnant females, this gives a mean figure of 3.2 litters per female per season. The yearly increase is then 7.4 young from one female. The difference obtained is relatively slight, as the result of the low mortality rate of whole litters during the basic reproduction period.

The estimated number of litters would seem to be fairly close to actual relations, and bearing in mind the occurrence of pregnant females in September it may be taken that the fourth litter is a real possibility for certain females in the population.

The yearly increase in young is in general in agreement with the data given earlier from more recent research on the hare. It would be useful, however, to check these results on larger series of pregnant females from consecutive months of the season and to compare data from several seasons.

\section{SEX RATIO}

The question as to what the real sex ratio is in hares under natural conditions is an important one in population research and is of consider- 
able value in assessing population increase. Sex ratio was examined in large series only during the hare shooting season, that is, chiefly during the winter and the interval in reproduction. Reciprocal proportions in the number of males and females obtained by samples from populations depend to a great extent on the method by which they are hunted or trapped (Szeder je i, 1959; Hell, 1960, and others). This is proved by the fact that the method used for collecting material greatly affects the results obtained, it being necessary to interpret results oblained in the light of a knowledge of animal biology. P u ce k (1960) discussed these problems in detail, using the shrew (Sorex araneus L i n n e u s, 1758) as an example, finding different sex ratios depending on the method of capture, the activity, age, sexual maturity, reproduction of the animals and similar factors. Andrzejewski \& Pielowski (1957) have discussed several of the population aspects of sex ratio in the case of the hare. These authors also give the distribution of variations in sex ratio over the course of one year on the basis of material taken from the study by Kolos ov \& Bakeev (1947). The results obtained (preponderance of females in the summer) suggest that this material, on account of the unequal monthly series and their origin from different areas at a distance from each other is unsuitable for this type of treatment. It is probable that it was not used for work on this problem by $\mathrm{Kol}$ os ov \& $\mathrm{Bakee}$ (l.c.) for that reason.

The ratio of males to females in the present material, composed of 764 specimens shot at random, was $398: 366$ (1:0.92). Distribution of sex ratio in successive monthly samples is illustrated in Fig. 10. The preponderance of males in the summer months (April-July) is noticeable here. This may be due to the greater activity in the area of the males, and primarily to the limited movements of females during the reproduction season. The peak value of the predominance of males in June was most certainly the result of the accidental distribution in monthly series of material relatively small in numbers for this type of study. The fact must be taken into account that the pregnant females lead a more concealed way of life and are less active at that time. During the interval in reproduction occurring in the autumn-winter months (from October to February), females are generally observed to predominate (sex ratio $1: 1.8$ ), while during the period when the females are pregnant i.e. from March to September, the ratio of males to females reveals a distinct predominance of males $(1: 0.77)$. The fact that a ratio close to $1: 1$ is obtained for the whole of the material is probably due to increased number of females shot during the autumn-winter 
period, when the "sitting" females are more likely to be shot by "potshots" (cf. also Szederjei, 1959).

The sex ratio of embryos is not encumbered with errors due to the method by which samples are taken, but it must be borne in mind that sex ratio at birth does not necessarily correspond to the ratio in a wild population, and even more so an exploited population.

Sex was determined for a total of 145 embryos at different stages of development in the material examined. It proved possible to determine histologically the sex of embryos over $35 \mathrm{~mm}$ long. With sizes of embryo over $70 \mathrm{~mm}$ it was usually possible to determine sex morphologically, some of these findings being additionally checked histologically.

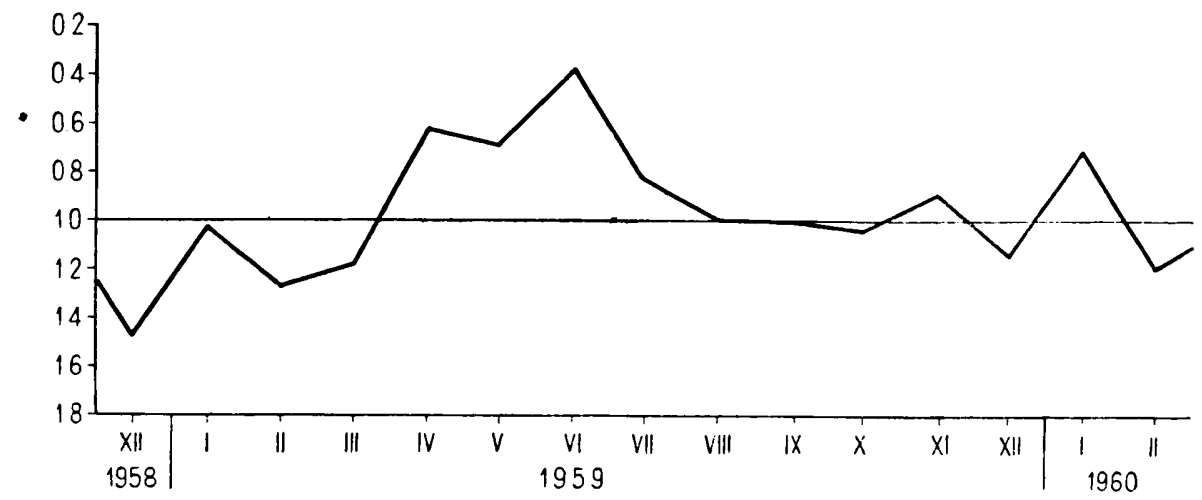

Fig. 10. Sex ratio in monthly samples.

The sex ratio of the embryos was 75 males and 70 females $(1: 0.93)$. The small series of material did not permit, it is true, of drawing conclusions with complete certainty, but the close similarity to the ratio obtained for the shot hares is remarkable.

It is quite understandable that the sex ratio in litters may be formed by the influence of a whole group of factors, and also of embryonic mortality. Data on the reduction in the number of males in litters in Sorex araneus during embryonic development are given by Mystk ow s k a (1959). In the present material in litters in which embryonic mortality was established, the sex ratio was $27: 22(1: 0.81)$, and in litters when mortality was absent as $1: 1(48: 48)$. The problem as to whether prenatal mortality in the hare does significantly regulate sex ratio and whether the female embryos are subject to greater intrauterine mortality requires confirmation on the basis of more abundant material. 
The real sex ratio in hares does not distinctly differ in the study area from the ratio $1: 1$, as is confirmed by the data given by $\mathrm{J}$ e $\mathrm{zi}$ e r ski (1959) obtained on abundant material from the whole of the Poznan province $(1: 1.04)$.

\section{SOME OTHER PROBLEMS OF REPRODUCTION PHYSIOLOGY}

1. The problem of superfoetation. Literature on this phenomenon is extensive, but is based on sporadic cases described in free-living hares. Superfoetation is, however, frequently observed in animals kept in captivity. Mating with highly pregnant females from $1-5$ or 8 days before birth was observed quite regularly (H e d i g e r, 1948; A l bert cited after Ocetkiewicz, 1961; Ocetkiew i c z, 1961). In the classical cases given by $\mathrm{H}$ e dige $r$ (1948) copulations led at that time to a new pregnancy and normal birth within a term indicating the effectiveness of coitus with pregnant females. It must be added that the males were kept isolated after mating with the pregnant females, which prevented repeated copulation. Ocetkiew i c z (1961) obtained 4 litters from one pair of captive animals within one year. From the data given on births it can be seen that superfoetation must have taken place in two cases, since births are separated by intervals of 34 and 39 days (cf. table 2, p. 25 of the work cited above). Similar observations are discussed by $\mathrm{Frag} \mathrm{u} g \mathrm{l}$ i o n e (cited after Ocetkiewicz, 1961) when two consecutive litters were separated by a period of 25 days. The fact must be emphasised that in all the cases described, when manifestations of superfoetation were present, the number of young born did not exceed two.

While the physiological mechanism of superfoetation in the hare is not completely explained, the view put forward by $\mathrm{S}$ ti e ve (1952), that superfoetation may take place primarily in cases in which the embryos from the first pregnancy are situated in one uterine horn, must be accepted as proved. In situations in which both uterine horns are occupied at the moment of copulation, the condition applies that the embryos present must be in the early stage of development, in order that the spermatozoa may penetrate to the oviducts between the egg and the uterine wall. In view of the opinion that ovulation in the hare

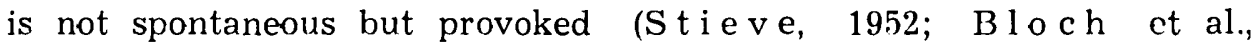
196.3) and that maturation of the successive Graafian follicles is not in any way inhibited in the hare by pregnancy and development of corpora lutea (B loch \& Strauss, 1958), the possibility of superfoetation occurring even when embryos are implanted in both uterine horns 
becomes understandable. In this way the phenomenon of superfoetation in the hare is treated by Hedige $\mathrm{r}$ (1948) and Stieve (1952) as physiological.

It might therefore be expected that fairly frequent cases would be found in the dissected material taken from free-living animals, of embryos in unequal stages of development, but only one certain case of this is known so far in literature (S t i e ve, 1952). The other observations given in hunting literature should be treated with reserve, since they were undoubtedly based on external inspection. Under these circumstances it is not possible to state with any certainty whether the differences in size observed are not the result of resorption of embryos which, as has been shown, takes place fairly frequently in the hare, particularly during the winter phase of reproduction.

Analysis was made on the study material, composed of pregnant females from the whole reproduction season, of the frequency of occurrence of one-sided pregnancies, including the possibility of an increas? in the number of such cases as the result of all the embryos in one horn being included in resorption. In the first months of reproduction cast $S$ of single-horn distribution of embryos were observed in a large number of 2 -foeti pregnancies. In the summer months (July) one-sided pregnancies were sporadically encountered even when there were $4-5$ foeti. It was found that resorption of embryos does not take the character of regulation of the overcrowding of embryos in the uterine horns. As conditions favourable to superfoetation were found in the initial phase of the reproduction season (numerous one-sided 1-and 2-foeti pregnances inspections of the whole material was made from this aspect, but a negative result was obtained, neither were any pregnant females encountered with embryos in different stages of development in the other months of the reproduction season. It was only in the case of a small number of females that situations were observed which might indirectly point to the possible occurrence of this phenomenon. In two females in advanced one-horn pregnancy small corpora lutea, which could be treated as the start of a new pregnancy, were found in the ovary corresponding to the free horn of the uterus, but possibly on account of the stage being too early no implanted embryos were found. In another female (from May) a foetus $65 \mathrm{~mm}$ long was found in the right horn of the uterus, which points to the second half of pregnancy, while in the ovary there were two corpora lutea $8 \mathrm{~mm}$ in diameter, forming evidence of the death of one embryo. In the left horn there was distinct enlargement of the uterus similar to that found in females immediately after birth. The left ovary contained clearly visible corpora 
lutea $9-10 \mathrm{~mm}$ in diameter. This female was lactating. Bearing in mind the still visible traces of parturition in the left horn and the fact of occurrence of lactation (according to $\mathrm{H}$ e dige $\mathrm{r}$, 1948, lactation lasts for about 3 weeks after birth), it would seem that superfoetation might have taken place in this case.

In the light of the observations presented, the concurrence with $\mathrm{R}$ i e ck's statement (1956) on the very limited significance of the pheno. menon of superfoetation to efficiency of reproduction under natural conditions is very obvious. Although the phenomenon itself of the single-horn distribution of embryos in the uterus is frequently observed under natural conditions, particularly during the winter phase of reproduction, cases of superfoetation are encountered only sporadically and cannot play an important part in the reproduction of the European hare.

2. Polyovular Graafian follicles. Bloch \& Straus (1958) did not find polyovular follicles in the ovary of the hare. In the case of the present material it proved possible to establish the occurrence of this phenomenon only indirectly, taking as a basis observations of embryos and the corpora lutea corresponding to them. Of all the pregnant females examined, it was only in two cases that the condition observed could be explained by the phenomenon of the ovulation of two eggs from one Graafian follicle. In female No. 377 from July there was single-horn pregnancy with separate and simultaneous development in the left uterine horn of 4 embryos measuring $30-35 \mathrm{~mm}$. The left ovary contained, however, only 3 distinct corpora lutea (diameter of $7 \mathrm{~mm}$ ). There were no traces of implantation in the right horn nor were there corpora lutea in the ovary corresponding to it. The second case was that of female No. 443, in the uterus of which there were 4 embryos $70-75 \mathrm{~mm}$ in size, one in the left horn, and three in the right. There were two corpora lutea in the right ovary (diameter $8 \mathrm{~mm}$ ), and one normal and a second smaller one (diameter $6 \mathrm{~mm}$ ) with a lighter zone in the centre - possible corpus atreticum in the left ovary. Under these circumstances the explanation may here be provided by polyovularity of the follicle in the right ovary. The above observations indicate that the phenomenon of polyovularity occurs in the hare to so small an extent that it cannot influence reproduction efficience. Scarcely $0.23 \%$ of polyovular follicles were found in the case of the rabbit in a very large series of material (A lle $n$ et al., 1947).

3. Migration of the blastocysts. It would seem that this phenomenon is a rare one in the hare. This is probably due to the 
type of structure of the uterus, making the movemerit of blastocysts within the uterus from one horn to the other difficult. The possibility of the blastocysts passing through the body cavity, as in the case of rabbits, must therefore be taken into consideration ( $\mathrm{Brambell}$, 1944). Only one case was observed in the whole of the material in which the lack of agreement between the number of foeti in the horns of the uterus and the corpora lutea corresponding to them was compensated by treating the whole of the genital organs jointly. In female no. 396 from August there was a total number of 5 normally developing embryos about $20 \mathrm{~mm}$ long arranged as follows: 1 in the left horn, 4 in the right. The ovaries contained respectively 2 and 3 corpora lutea of equal size ( $9 \mathrm{~mm}$ diameter). This case can be explained by assuming that the blastocyst had migrated from the left to the right horn of the uterus.

4. Single-egg twins. Only one case was encountered in which it was very probable that this type of twin pregnancy had occurred. In a female from August (no. 442) 4 foeti about $40 \mathrm{~mm}$ long were found, of which one was situated in the right horn and had 1 corpus luteum corresponding to it, while 3 were situated in the left horn. Two_ of these, situated nearer the cervix of the uterus, were contained in one foetal thickening not differing in dimensions from the remainder (about $45 \times 35 \mathrm{~mm}$ ). The left ovary had 2 normal corpor: lutea, 9 and $10 \mathrm{~mm}$ in diameter, and one smaller one, $6 \mathrm{~mm}$ in diameter, probably corpus luteum atreticum. The degree of fixation of the embryos did not permit of a detailed estimate of the formation of the foetal membranes, but there was a joint placenta for both, and both embryos were of the same sex (females). Apart from the case described above, no other instance of the occurrence of two embryos in a joint foetal cell in so early a phase of embryonic development was encountered.

5. Distribution of embryos in the uterus. Vale $n$ tincic (1955) found in a total of 33 pregnant females that in the great majority of the cases the embryos were distributed in the left uterine horn. In the present material the distribution of normally developing embryos in the left and right horns was $103: 107$, considerable differences being found between the different months (e. g. in March the relation was $11: 22$, in July $19: 10$ ). It is possible to speak in this case of an accidental distribution, primarily determined by ovulation. On account of the absence of the regulating effect of migration of the blastocysts, distribution is subject to changes only as the result of embryonic mortality. The influence of embryonic mortality was exami- 
ned in detail to establish whether it was influential in reducing the numbers of young in very large litters, but comparison of data shows that there is no such tendency. Usually less than half the embryos develop in relation to the number of ovulated egs, yet irrespective of of the ovulation level as a rule only one embryo dies (Tab. 5). It would therefore seem that in the case of the hare embryonic mortality does

Table 5.

Frequency and intensity of embryonic mortality depending on the number of ova ovulated.

\begin{tabular}{|c|c|c|c|c|c|c|c|c|c|c|c|}
\hline \multirow{4}{*}{$\begin{array}{l}\text { No. of ova } \\
\text { ovulated }\end{array}$} & \multirow{2}{*}{\multicolumn{5}{|c|}{ Hortality of embryos }} & \multicolumn{3}{|c|}{ Wo. of females } & \multirow{4}{*}{$\begin{array}{l}\text { lio. cf cra } \\
\text { ovulated }\end{array}$} & \multirow{2}{*}{\multicolumn{2}{|c|}{ Total inortality }} \\
\hline & & & & & & \multirow[t]{3}{*}{$\mathrm{N}$} & \multirow{2}{*}{\multicolumn{2}{|c|}{$\begin{array}{c}\text { Insluding enbrionic } \\
\text { mortality }\end{array}$}} & & & \\
\hline & \multirow[t]{2}{*}{1} & \multirow[t]{2}{*}{2} & \multirow[t]{2}{*}{3} & \multirow[t]{2}{*}{4} & \multirow[t]{2}{*}{5} & & & & & \multirow[b]{2}{*}{$n$} & \multirow[b]{2}{*}{$\mathfrak{x}$} \\
\hline & & & & & & & $\mathrm{n}$ & $\dot{x}$ & & & \\
\hline 1 & 8 & & & & & 19 & 8 & 42.1 & 19 & 8 & 42.1 \\
\hline 2 & 7 & 5 & & & & 23 & 12 & 52.2 & 46 & 17 & 36.9 \\
\hline 3 & 8 & 3 & 3 & & & 26 & 14 & 53.8 & 78 & 23 & 29.5 \\
\hline 4 & 8 & 3 & - & 4 & & 27 & 15 & 55.6 & 108 & 30 & 27.8 \\
\hline 5 & 6 & 1 & - & - & 3 & 12 & 10 & 83.3 & 60 & 23 & 38.3 \\
\hline \multicolumn{6}{|c|}{ Total } & 107 & 59 & 55.1 & 311 & 101 & 32.5 \\
\hline
\end{tabular}

not play the part of factor regulating the distribution of embryos in the uterus of the females. The abnormal distribution of foeti and their concentration or even crowding in one horn takes place as a separate phenomenon, completely independently, and is frequently observed.

\section{DISCUSSION}

1. The reproduction season in the hare as established in the present study coincides in time with data for similar geographical conditions. Information taken from wildlife studies show that in Poland the beginning of the oestrus takes place during the period from January to March (Krawczyński, 1924; $\mathrm{H}$ aber \& $\mathrm{Nunber}$, 1956; $\mathrm{Budzy}$ nk i, 1953). Stieve (1952) gives the start of oestrus for Central Germany as the end of January and beginning of February. In the Ukraine the breeding season usually begins in mid- February (K o r n e e v, 1960), and in Lithuania at the end of January and in February and at the beginning of March, changes beginning in the gonads in December-January (L i k e vi č i e n é, 1962).

In studying the reproduction of the European hare over its geographical range the considerable degree of agreement in the times of reproduction is remarkable. In Rumania oestrus lasts from January to the end of August (S c a r late s c u et al. 1963). In the eastern part of the range, in the region near Caucasus Mts., the principal reproduction period begins in the winter, in January and February. It is only in the 
northern part of the hare's range in the Soviet Union that oestrus begins later and the first pregnant females appear as late as March (Kolosov, 1941; Kolosov \& Bakeev, 1947). Popov (1960) states that in the region between the Volga and Kama rivers distinct manifestations of oestrus in the hare were observed in the form of traces of bloodstained urine on the snow in that area at the end of February, and examination of pregnancies showed that oestrus begins at the beginning of March. Reynolds \& Stinson (1959) state that in Canada the reproduction season of the hare lasts from January to August.

Over the whole of its range, even in places where the hare reproduces throughout almost the whole year (Caucasus) the seasonal and cyclic character of reproduction is clearly expressed in the number of pregnant females and in the weight and size of the gonads. The smallest dimensions of the gonads occurred in the present material in the case of males in September and October, and in females in November and December. S c a r l a te scu et al. (1963) give identical results as the mean values from several districts in Rumania. In the Caucasus area the lowest percentages of sexually active males and pregnant females are those for October-December, with a minimum in November, the curve of pregnancy capacity exhibiting considerable reduction as from September and a sharp rise in January (Kolosov, 1941). A similar curve of pregnancy capacity for the females is given by Reynolds \& Stinson (1959) for Ontario.

2. Within the whole range the reproduction cycle of the hare is subject to distinct fluctuations in different years. It would seem that these differences are more connected with the time at which reproduction begins than when it ends, or becomes less intensive. These variations, usually connected with changes in climatic conditions, result in pregnant females being encountered exceptionally early in mild winters. Cases like this are noted only sporadically under the conditions prevailing in Poland. $\mathrm{H}$ a y (1953) states that a lactating female was encountered on December 4th 1952. K or ne ev (1960) gives several instances of pregnancy in females in different years in the Ukraine in the following months: November, December and January. During mild winters pregnant females are encountered throughout the whole year in Jithuania (L ikeviči e né, 1962). Sexually active males were encountered from October to December in Germany (Stie ve, 1952). This author connects the time at which oestrus begins with the temperature and type of weather in the winter. Sexually active males occurred in December in the present material in both the study years, 
which differed as to the time at which the first pregnancies began. This led to the conclusion that the true moment at which reproduction begins is determined by the occurrence of oestrus in females. Bearing in mind that the occurrence of oestrus in females must be connected with their proper readiness for pregnancy, constituting a considerable effort at this time for an organism enfeebled by the unfavourable conditions in winter, it is quite understandable that the moment of appearance of sexual activity may differ in time between the two sexes.

Comparison of the two winter periods from the aspect of climatic conditions shows that the winter of $1958 / 1959$ was milder than that of $1959 / 1960$. This was expressed in the mean values for periods of 10 days and the monthly averages of atmospheric temperature. The mean value for December 1958 on the meteorological station at Koło in the study area was above freezing point $\left(+1.2^{\circ} \mathrm{C}\right)$. A drop in temperature occurred in January $\left(-0.8^{\circ}\right)$, and in February $\left(-1.6^{\circ}\right)$. The lowest mean value for a 10 -day period (from 10 th-20th January) was $-3.6^{\circ} \mathrm{C}$. In the winter of $1959 / 1960$ the average temperature for December was $+0.2^{\circ}$. Corresponding values for January and February were respectively -2.3 and $-3.4^{\circ}$, the lowest temperature for a 10-day period being $-6^{\circ}$ in January and $-9.4^{\circ}$ for February. Differences between these seasons were also expressed in the monthly sum total of precipitation, December 1959 and January 1960 having higher values. This last fact is of considerable importance here, as it may be related to the thickness of snow covering. There are, however, no special field observations of the thickness and structure of the snow covering and the standard meteorological data are of little use here, as they do not refer to the hare's environment. It may be assumed that a far more important factor to the hare than the temperature itself is the snow covering, making natural food difficult of access. The food of the hares living in the study area, chiefly in cultivated fields, was probably mainly winter corn, which forms green food of the greatest value to the hare during this period. The accessibility of this food, depending on patches of the fields being left bare of snow, should have a considerable effect on the condition of hares in the winter period. Mild winters, during which reproduction begins far earlier, probably create better food conditions for the hare population. According to $\mathrm{S}$ i i v o n e $\mathrm{n}$ (1956), under the conditions prevailing in Finland the thickness of the snow covering exerts a significant effect on fluctuations in the numbers of the hare. Deterioration of conditions, making it difficult to obtain food, is revealed by reduction in reproduction during the reproduction season following the winter. The observations made by Lechleitner 
of L. californicus bear out the assumption that food conditions influence reproduction. This author endeavours to explain the simultaneous occurrence of sexually active and inactive adult animals by the conditions of the habitats in which they live. Animals living in wet areas where plants remain green throughout the year, can participate in reproduction without interruption. He found that for $L$. californicus, as for the European rabbit, the factors affecting reproduction would seem to be connected with the yearly cycle of precipitation and the vegetation depending on it; light plays an unimportant part here.

Under the climatic conditions of Central and Eastern Europe the autumn-winter interval in reproduction in the hare is biologically justified, since severe winter conditions make it impossible to rear young. This period is also the worst for the population on account of food conditions, and the view would therefore seem reasonable that the seasonal character of climatic and plant conditions may influence the time of sexual activity and reproduction of the hare.

3. Many observations indicate that in discussing problems of reproduction it is impossible to omit the influence of the population structure of hares (A ndrzejewski \& Pielowski, 1957). Assuming that under normal conditions the sex ratio is approximately $1: 1$, the problem of the age structure of the population becomes of primary interest. The reciprocal proportions of the age groups are formed primarily in connection with intensivity of reproduction, both at different periods of the season and over the whole of the reproduction season, and also depend on the mortality among young hares, particularly, according to $\mathrm{Rieck}$ (1956) during the autumn of intensive coccidiosis. During shooting seasons preceded by the so-called "good years" for hares, more young animals are as a rule observed in the population than is normal. The problem of the importance of young hares to reproduction in the following season is connected with the question of the time necessary to attain sexual maturity and the intensivity of reproduction in this group of the population.

The increase from the first litter of the season was examined in detail by $\mathrm{R}$ i e ck (1956), who became convinced that the possible reproduction by the oldest animals among those born the same calendar year in the same reproduction season cannot affect population numbers. An analysis of the present material provided grounds for a similar conclusion. In the light of these views it is possible to question whether the conclusions drawn by $\mathrm{Hell}$ \& F a r ka s (1963) on the basis of the distribution of the body weight of the hare from the autumn-winter months are in fact correct. These authors state that a small group of 
hares weighing about $2.80 \mathrm{~kg}$ can be distinguished on the curve of body weight and assume that these are the young hares produced in the autumn by females born earlier the same year. This fact rather proves that a later autumn litter was produced by part of the adult females in the population in the study years, but is not a convincing argument that females reproduce in the first year of their lives.

The time at which sexual maturity is attained by the young hares has been defined by $\mathrm{R}$ i e ck (1956) as about 8 months. Koene $\mathrm{n}$ (1956) states that hares born in the early spring are sexually mature by the autumn, but do not participate in reproduction until the following year. The material exmined in the present study indicates that sexual maturity may be attained within a shorter period, but this problem should be considered in close connection with intensification of sexual activity in a population. It was found that males can maturate earlier than females, at the age of about $5-7$ months, even sporadically in the first calendar year of life. Correspondingly the time taken for females to begin reproduction at the beginning of the new season can be taken as 7 months. In her examinations of reproduction in captive animals Ocetkiewicz (1961) described a case in which a female born on 16th August 1956 gave birth to its first young on April 19th of the following year, that is, when 8 months old. Fertilisation must therefore have occurred in this case before the female was fully 7 months old.

On the basis of the present material it may be stated that it is the hares several years old and the oldest hares from the previous year which first begin reproduction at the start of the season, while the maturation of the youngest hares, that is, those born in the second half of the reproduction season, takes place noticeably later. The observations made by Kolosov (1941) that females which breed later in the first phase of reproduction have a larger number of embryos than those which have entered upon the second pregnancy in the same season, is very interesting.

4. The number of litters from one female during the season continues to form a debatable question in relation to the hare. $\mathrm{Rieck}$ (1956) in analysing Valentincic's 1956 material finds that female hares cannot produce five litters in one season in Jugoslavia. He accepts as a fact that under the geographical conditions of Central Europe $3 / 4$ of the females produce four litters yearly, and $1 / 4$ - three litters. Under exceptionally favourable conditions a fifth litter may occur. In the southern region of the European part of the Soviet Union, on the steppes of the Caucasian area Kolos ov \& Bake e v (1947) find that three or four litters occur, depending on the climatic condit- 
ions in a given year. This is due to curtailment of the true reproduction season as the result of drought occurring in the second half of the summer. In the Ukraine $\mathrm{Averin} \& \mathrm{M}$ igulin (cited after $\mathrm{K}$ olos ov \& Bakeev, 1947) found that four, or three to four, litters occur in one season. In the central zone of the European part of the Soviet Union the hare is held to produce only two litters a year (K olosov \& Bakeev, 1947). Ocetkiewicz (1961) found that in animals kept in captivity four litters are produced by one female during a season lasting from March to August. It would therefore seem that the annual number of litters depends on how long the reproduction season lasts, and should therefore be smaller when the season starts late. Under normal conditions it should be taken that three litters appear yearly as a rule.

5. The amount of the increase and of the numbers in litters depend to a great extent on the embryonic mortality rate. It would seem that the phenomenon of resorption of embryos in the early stages of their development plays a decisive part here. Kol o s o v (1941) found differing degrees of intensity of resorption over the season - a high degree in the winter reproduction period (18\% of dead embryos) and autumn $(25 \%)$, and the smallest in the spring $(7 \%)$. R e ynolds \& Stins o n (1959) found a low degree of prenatal mortality; of a total of 211 pregnant females resorption occurred only in five cases, 4 of which took place during the winter months. There was very considerable embryonic mortality in the material used for this study. It must be emphasised that at the end of the summer when reproduction intensity declines no increase, but even a decrease in resorption and total embryonic mortality was observed. K o l o s ov (1941) explains increased resorption by the occurrence of conditions unfavourable to reproduction in the winter, and also in the autumn when there is a drought. In the present material the increased mortality observed in the summer, during the months with optimum food conditions (May, June), indicates the existence of other causes. It would seem possible that mortality during the winter is connected with the incomplete readiness of the females for reproduction or with vitamin deficiency. The effect of vitamins on reproduction has been discussed in detail by $\mathrm{S} \mathrm{chwartz}$ (1942), in examining resorption in Sylvilagus floridanus. Mortality in May and June may be caused by the exhaustion of the females as the results of pregnancies and lactation, since the results obtained suggest that in the majority of the females the first pregnancy was immediately followed by the second. Increase in embryonic mortality in lactating females was established in the case of the rabbit by $\mathrm{Brambell}$ 
\& M ills (1948). A period of increased mortality is probably followed by a slowing down of the rate of reproduction and a state of physiological equilibrium in the second half of the summer. The end of reproduction is characterised by a relatively low mortality rate. Mortality before implantation and resorption are not the only factors which reduce the size of the litters. The occurrence of abortion and mortality in the later stages of intra-uterine development must also be taken into consideration. $\mathrm{H}$ a y (1955) described cases of finding mummified ioeti in the final stages of pregnancy in the uterus, and similar cases were noted for Sylvilagus and the domestic rabbit (Schwartz, 1942). It would appear that this latter phenomenon occurs sporadically and is not of any great significance in reproduction, since no such cases were encountered in the large amount of material dealt with in the present study.

6. The different litters during the reproduction season are not of equal importance to population increase in the case of the hare. This is shown both by the numbers of young per litter and the capacity of the young for survival. It is generally accepted that the first young born in February and March as a rule die on account of the unfavourable conditions prevailing in the winter and early spring. In addition these are small litters as a result of the low ovulation level and high mortality rate at this time. The final litters produced by a small number only of the females, do not grow fully before the winter and are more susceptible to the autumn epizootics. R i e ck (1956) found, on the basis of analysis of material from shoots, that a considerable number of the young hares die from coccidiosis in a wet autumn. The malerial examined in the present study shows that the spring reproduction period, including the months of March and April, proved to be the most favourable to population increase, the greatest number of embryos developing during this period, with simultaneous minimum embryonic mortality rate. The young animals from this period are born in April and May and are able to develop well during the summer and therefre enter upon the winter period in good condition. $R$ i e ck's results (1956), based on extensive field material, show that almost half the population increase originates from May and June. Field observations form in this case reliable confirmation of the results obtained from morphological examination of the genital organs.

The character of reproduction in the study year 1959 is also interesting on account of the fact that it was a so-called "good year" for hares. In comparison with other years there was a very considerable increase of young hares that year in the Poznan province ( $\mathrm{J}$ e zier- 
ski, in preparation). The fact that this year was also favourable to increase in the number of hares in Germany ( $\mathrm{R} \mathrm{i} \mathrm{e} \mathrm{ck,} \mathrm{1962)} \mathrm{sugg-}$ ests that more general causes than population ones were involved here, probably connected with climatic conditions. Lack of material makes it impossible to compare reproduction intensity in years with different increases of young hares in the autumn. It would, however, seem that the relations described may be subject to certain deviations in successive years. The time at which reproduction begins and its intenssity, particularly during the spring period, undoubtedly influence the size of the real increase. The autumn mortality of young hares treated as the fundamental cause of variations in the population numbers of the hare ( $\mathrm{N} \mathrm{a} \mathrm{u} \mathrm{mov,} \mathrm{1938;} \mathrm{R} \mathrm{i} \mathrm{e} \mathrm{k,} \mathrm{1956)} \mathrm{may} \mathrm{also} \mathrm{be} \mathrm{casually} \mathrm{connected}$ with reproduction, since different degrees of intensity of reproduction over the reproduction season form the age structure of the young hares in a population.

\section{RESULTS}

The breeding season in the two winter periods studied, 1958/59 and 1959/60, began in the case of the males in December. Sexually active males occurred up to September 1959.

The first pregnant females were found in January 1959 and February 1960. The last pregnancies were observed in the second half of September.

When comparison was made of the two successive starts of the reproduction season, distinct differences were found between them in respect of the month's delay in the appearance of pregnancies in females in 1960, and the percentage of sexually inactive males, greater than in the perceding season. in the first months of their activity.

The peak values for size of the gonads characterising the maximum sexual activity occurred in March in the case of males and in April in females.

The maximum regression of testes was observed in the majority of the males in September and October. The dimensions of the ovaries are greatest in November and December.

Two cases were observed in the material of the attainment of sexual maturity by young females in the year of their birth. Only sporadic tendency to maturation occurred in young females, interrupted by the total regression of the gonads in the autumn. Maturation of the young hares took place normally during the oestrus at the beginning of the reproduction season later on, after the renewal of the reproductive functions in adult animals, at the minimum age of $5-7$ months in males and $7-8$ months in females.

The ovulation level, lowest in the first month of reproduction (on an average about 1 egg per female) rises sharply up to April and is maintained on a high level (average about 4 eggs) until June. In the second half of the summer there is a decrease in the level of approximately 4 ovulated eggs per female.

The number of implanted embryos is smallest in the first litter - being about 1-1.5 per female in January and February and largest in April (4.0). It then remains on a high level ( 3 or more embryos) until the end of the season.

Embryonic mortality (particularly resorption) was found to have a significant 
effect on calculation of the size of litters. The highest mortality rate was observed at the beginning of the reproduction season and in May and June. Embryonic mortality was found to decrease in the final phase of the season.

The highest percentage of pregnant females occurred in February-April and in June and July. This points to the probable occurrence of three principal litters during the year. The calculated mean number of litters is 3.4 per female during the season.

The average size of the litter, after allowing for embryonic mortality, was 2.3 young per female. The annual increase in young hares per female is between $7-8$ young. The second litter born during the April-May period is of fundamental importance to population increase.

The ratio of males to females in the material composed of shot hares is $398: 366(1: 0.92)$, and in the case of embryos is $75: 70(1: 0.93)$.

Out of a total number of 270 embryos studied, it was only in two cases that the possibility of superfoetation having occurred could be taken into consideration.

A few isolated cases were observed of polyovularity of the Graafian follicle, migration of blastocysts and single-egg twins.

Acknowledgments: It is $\mathrm{mv}$ pleasant duty to thank Dr. Zdzisław $\mathbf{P u c e k}$ for his help and guidance in preparing this study, and Dr. Andrzej K. Tarkow$\mathrm{s} \mathrm{ki}$ for reading the typescript and for his valuable comments.

\section{REFERENCES}

1. A d a m czewska, K. A., 1961: Intensity of reproduction of the Apodemus flavicollis (Mel chior, 1834) during the period 1954-1959. Acta theriol., 5, 1: 1-21. Białowieża.

2. Alle n, P., Brambell, F. W. R. \& Mills, I. H., 1947: Studies on sterility and prenatal mortality in Wild Rabbits. I. The reliability of estimates of prenatal mortality based on counts of corpora lutea, implantation sites and embryos. J. Exp. Biol., 23, 3-4: 312-331.

3. Andrzejewski, R. \& Pielowski, Z., 1957: O koniecznosci pogłębienia badań populacyjnych nad zającem (Lepus europaeus Pal1.). Ekol. pol. B 3, 4: 293-299. Warszawa.

4. B loch, S., Hedig e r, H., Müller, C., Strauss. F., 1954: Probleme der Fortpflanzung des Feldhasen. Rev. Suisse Zool. 61, 3: 485-490. Genéve.

5. Bloch, S., Hediger, H., Mülle r, C. \& Strauss, F., 1963: Die Kontrolle der Genitalzyklen beim Feldhasen durch Vaginalabstriche. Säugetierkdl. Mitt., 11, 4: 186-187.

6. Bloch, S. \& Strauss, F., 1958: Die weiblichen Genitalorgane von Lepus europaeus Pallas. Z. Säugetierkde, 23, 1-2: 66-80.

7. B rambell, F. W. R., 1944: The reproduction of the Wild Rabbit, Oryctolaqus cuniculus (L.) Proc. zool. Soc. Lond., 114: 1-45.

8. Brambell, F. W. R. \& Mills, J. H., 1947: Studies on sterility and prenatal mortality in Wild Rabbits. III. The loss of ova before implantation. J. Exp. Biol., 24, 1-2: 192-210.

9. Brambel1, F. W. R., 1948: Studies on sterility and prenatal mortality in Wild Rabbits. IV. The loss of embryos after implantation. J. Exp. Biol., 25, 3: $241-269$, 
10. Budzyński, E., 1953: Zając hodowla i polowanie. Państwowe Wydawnictwo Rolnicze i Leśne: 1-68. Warszawa.

11. Bujalska, G., 1964: Studies on the European hare. IV. Variations in the pelvis and sacrum. Acta theriol. 9, 18: Bialowieża.

12. Bujalska, G., Caboń-R a c z yńska, K. \& R a c z y ńs ki, J., (in preparation): Studies on the European hare. VI. Comparison of different criteria of age. Acta theriol., 10.

13. C a boń-R a c zýs k a, K., 1964a: Studies on the European hare. II. Variation in the weight and dimensions of the body and the weight of certain internal organs. Acta theriol., 9, 16: Białowieża.

14. Caboń-R a czyńska, K., 1964b: Studies on the European hare. III. Morphological variability of the skull. Acta theriol., 9, 17: Białowieża.

15. Godlewski, E. jun., 1956: Embriologia zwierząt kręgowych ze szczególnym uwzględnieniem człowieka. Państwowe Zakłady Wydawnictw Lekarskich: 1-414. Warszawa.

16. H a ber, A. \& Nunberg, M., 1956: Zoologia dla leśników. Państwowe Wydawnictwo Rolnicze i Leśne: 1-794. Warszawa.

17. Hay, J., 1953: Wyniki badań schorzeń zajęcy $z$ odstrzału 1952/53. Eowiec pol., 9 (1018): 138-139. Warszawa.

18. He diger, H., 1948: Die Zucht des Feldhasen (Lepus europaeus Pallas) in Gèfangenschaft. Physiol. Comp. et Oecol., 1, 1: 46-62. Haag.

19. Hell, P., 1960: Pomer pohlavia u zająca (Lepus europaeus P a 11.) Zool. Listy. 9 (23), 1: 83-88. Praha.

20. H e 11, P. \&. F a rk a š, L., 1963: Telesná váha a jatočná výtažnost u zajaca polného (Lepus europaeus $\mathrm{P}$ al1.) $\mathrm{V}$ období jeho polovníckeho využívania. Sborník VSP v Nitre: 217-230.

21. Jezierski, W., 1959: Wyniki badań nad zającem w województwie poznańskim. Łowiec pol., 18 (1117): 2-5. Warszawa.

22. Jezierski, W., in preparation.: Studies on the European hare. VII Changes in some elements of the structure and size of populations. Acta theriol., 10.

23. Koenen, F., 1956: Der Feldhase. Die Neue Brehm-Bücherei, A. Ziemsen Verlag: 1-80. Wittenberg Lutherstadt.

24. Kolosov, A. M., 1941: Biologia rozmnoženia zajca rusaka (Lepus europaeus $\mathrm{P}$ a 11.) Zool. Z. 20, 1: 154-172. Moskva.

25. Kolosov, A. M., \& B k e ev, N. N., 1947: Biologia zajca-rusaka. Izd. Mosk. Obšc. Isp. Prir., 1-103. Moskva.

26. Korneev, O. P., 1960: Zajec-rusak na Ukraini. Wydav. Kiivskogo Univ.: 1-107. Kiev.

27. K r a w c y ński, W., 1924: Eowiectwo. Gebethner i Wolff: 1-380. Kraków.

28. Le chleitner, R. R., 1959: Sex ratio, age classes and reproduction on the black-tailed Jack Rabbit. J. Mamm., 40, 1: 63-81.

29. Likevičiené, N., 1962: Ekologia zajca rusaka v uslovijah litovskoj SSR. Vtoraja zool. konferencja litovskoj SSR: 61-63. Vilnius.

30. Mystkowska, E. T., 1959: Cytologische Methode der Geschlechtsbestimmung bei Embryonen und das Geschlechtsverhältnis bei Fetus von $S$. a. araneus L. Acta theriol., 3, 9: 121-140. Bialowieża.

31. Na umov, S. P., 1937: Kolebanija čislennosti u zajcev. Woprosy ekologii i biocenologii: 40-82. Moskva, 
32. N a umov, S. P., 1960: Sroki rozmnoženija i ploduvitost $v$ niekotoryh populacjach Lepus timidus L. Sb.: „Issledovanija pricin i zakonomiernostiej dynamiki čislennosti zajca bieljaka v Jakutii": 55-68. A. N. SSSR. Moskva.

33. O c etki e wi c z, J., 1961: Zagadnienia hodowli klatkowej zająca-szaraka (Lepus europaeus $\mathrm{P}$ a $11 \mathrm{as}$ ) i wyniki uzyskane w warunkach krajowych. Inst. Z̃oot. Wydawnictwa Własne. 122: 1-48. Kraków.

34. Pielowski, Z., 1962: Uber ökologische Forschungen am Feldhasen in Polen. Beitr. Jagd- und Wildforsch. 2, 55: 41-52. Berlin.

35. Pierevalov, A. A., 1956: Materialy po biologii razmnaženia zajca pieš̌anika. Zool. Z., 25, 1: 141-154. Moskva.

36. Popov, V. A., 1960: Mlekopitajušcije volžko-kamskogo kraja. Akad. Nauk. SSSR: 1-465. Kazan.

37. Pucek, Z., 1959: Some biological aspects of the sex-ratio in the Common shrew (Sorex araneus araneus L.). Acta theriol., 3, 4: 43-73. Bialowieża.

38. Reynolds, J. K. \& Stinso n, R. H. 1959: Reproduction in the European hare in Southern Ontario. Can. J. Zool., 37, 5: 627-631.

39. Rieck, W., 1956: Untersuchungen über die Vermehrung des Feldhasen. Z. Jagdwiss., 2, 11: 49-90. Hamburg.

40. Rieck, W., 1962: Analyse von Feldhasenstrecken nach dem Gewicht der Augenlinse. Supp. Ricerche Zoologie App. Caccia 4: 21-29.

41. Scarlatescu, G., A l m a s a , H., Nesterov, V., 1963: Contributil la cunoasterea biologiei iepurelui in R. P R. Studii si Cercetari. 23-A: 97-118. Bucuresti.

42. S chwartz, C., 1942: Breeding season of the Cottontail in Central Missouri. J. Mamm., 23, 1: 1-16.

43. Si ivonen, L., 1956: The correlation between the fluctuation of partidge and European hare populations and the climatic conditions of winters in South-West Finland during the last thirty years. Papers Game Res. 17: 1-30. Helsinki.

44. Stieve, H., 1952: Zur Fortpflanzungbiologie des europäischen Feldhasen (Lepus europaeus P a 11 a s). Zool. Anz. 148, 5-8: 101-114.

45. Szederjei, A., 1959: Beobachtungen über den Feldhasen in Ungarn $Z$. Jagdwiss., 5, 3: 31-94. Hamburg.

46. Valentincic, S. I., 1956: Resultate zweijähriger Beobachtungen und Studien über den idealen Zuwachs bei Feldhasen auf der Insel "Biserni Otok". Z. Jagdwiss., 2, 3: 152-160. Hamburg.

47. Valentincic, S. I., 1961: Beweis der Trächtigkeit einer Junghasin. Z. Jagdwiss., 7, 4: 137-139. Hamburg.

Polish Academy of Sciences, Mammals Research Institute, Białowieża, woj. Białystok.

\section{STRESZCZENIE}

Badania oparto na materiale organów rozrodczych z serii 765 zajęcy, odstrzejonych na terenie województwa poznańskiego $w$ czasie 15 kolejnych miesięcy nd XII. 1958 - II. 1960 r. (Tab. 1.). Pobierane z populacji próby miesięczne byly losowe i liczyły ca. 50 osobników każda. Dodatkowo przebadano gonady 72 samfów o określonym wịeḳu, 
U samców analizowano cykl sezonowej zmienności jąder oraz przebieg spermatogenezy, u samic rozmiary jajników i rogów macicy, obecność ciałek żóltych i zarodków oraz zjawiska śmiertelności zarodkowej.

Uzyskano następujące wyniki:

Sezon rozrodczy w dwóch badanych okresach zimowych: 1958/59 i 1959/60 rozpoczął się u samców w grudniu. Aktywne płciowo samce występowaly do września 1959 roku (Tab. 2).

Pierwsze ciężarne samice stwierdzono w styczniu 1959 roku i w lutym 1960 roku. Ostatnie w sezonie ciąże obserwowano w drugiej połowie września (Tab. 3).

Przy porównaniu dwóch kolejnych początków sezonu rozrodczego stwierdzono między nimi wyraźne różnice, wyrażone w późniejszym o miesiąc pojawieniu się ciąż u samic w 1960 roku oraz w większym niż w poprzednim sezonie procencie nieaktywnych płciowo samców w pierwszych miesiącach ich aktywności.

Szczytowe wartości wielkości gonad, charakteryzujące maksimum aktywności płciowej, przypadły dla samców w marcu dla samic w kwietniu (Ryc. 1, 5).

Największą regresję jąder obserwowano u ogółu samców we wrześniu i październiku. Jajniki wykazują najmniejsze rozmiary $w$ listopadzie i grudniu.

W materiale obserwowano $w$ dwóch przypadkach osiągnięcie dojrzałości płciowj przez młode samce $w$ roku urodzenia. U młodych samic występowała jedynie sporadycznie tendencja do dojrzewania, przerwaną ogólną regresją gonad na jesieni. Dojrzewanie młodych zachodzi normalnie $w$ okresie rui na początku sezonu rozrodczego, nieco później po wznowieniu funkcji rozrodczych u dorosłych zwierząt, w wieku minimalnie od 5-7 miesięcy życia u samców i $7-8$ u samic.

Poziom owulacji, najniższy w pierwszym miesiącu rozrodu (średnio około 1 jajo na samicę), rośnie gwałtowníe do kwietnia i utrzymuje się na wysokim poziomie (średnio około 4 jaj) do czerwca. W drugiej połowie lata następuje spadek do poziomu około 3 jaj owulowanych średnio na samice (Ryc. 7).

Ilość implantowanych zarodków jest najniższa w pierwszym miocie - w styczniu i lutym i wynosi około $1,0-1,5$ na jedną samicę a najwyższa w kwietniu $(4,0)$. W pozostalym okresie do końca sezonu utrzymuje się na wysokim poziomie (3 i więcej zarodków na samice)).

Stwierdzono duży wpływ śmiertelności zarodkowej (szczególnie resorpcji) na obniżenie wielkości miotu. Największą śmiertelność obserwowano na początku sezonu rozrodczego oraz $\mathrm{w}$ maju i czerwcu. W końcowej fazie sezonu stwierdzono spadek śmiertelności zarodkowej.

Najwyższy' procent ciężarnych samic wystąpił w lutym, kwietniu oraz w czerwcu i lipcu. Wskazuje to na możliwość występowania trzech zasadniczych miotów w ciągu roku. Wyliczona średnia ilość miotów $w$ sezonie wynosi 3,4 od samicy.

Srednia wielkość miotu, po odliczeniu śmiertelności zarodkowej wynosi 2,3 młodych na samice. Roczny przyrost młodych od jednej samicy zawiera się między liczbą 7 a 8 sztuk. Zasadnicze znaczenie dla przyrostu populacji zająca posiada drugi miot, przypadający na kwiecień - maj.

Stosunek samców do samic $w$ materiale odstrzelonych zajęcy ma się jak $398: 366(1: 0,92)$, u zarodków zaś jak $75: 70(1: 0,93)$.

$\mathrm{Na} 270$ badanych zarodków w dwóch przypadkach można było wnioskowa6 pośrednio o możliwości wystąpienia superfetacji.

W pojedynczych przypadkach obserwowano poliowularność pęcherzyków Graafa, wędrówkę blastocyst i bliźnięta jednojajowe. 